البحث الرابـ:

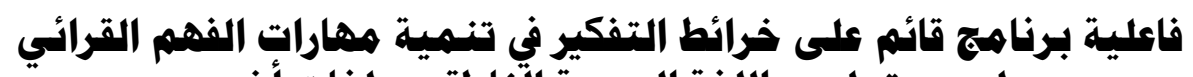
لدى متعلمي اللغة العربية التناطقين بلغية فهات أخرى النها

\title{
إعقاق :
}

د/ بلدر بن هديبان هلال الحربي

معهد تعليم اللغة العربية

الجامعة الإسلاميلة بالمدينة المنورة العربية 



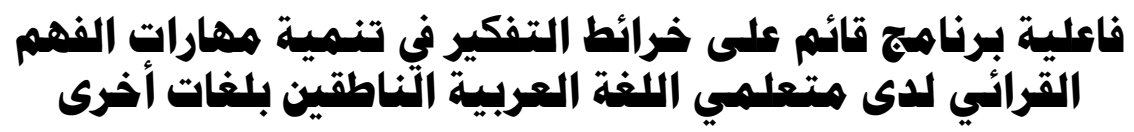

د/ بلدر بن هليبان هلال الهربي

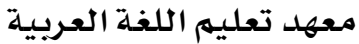

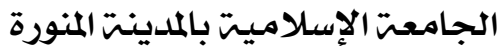

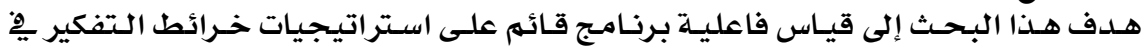

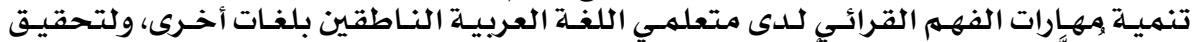

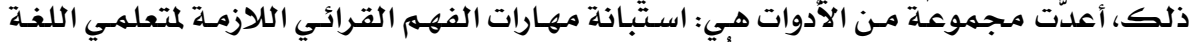

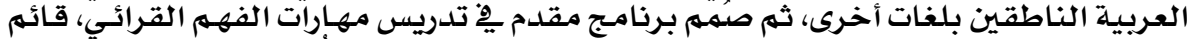

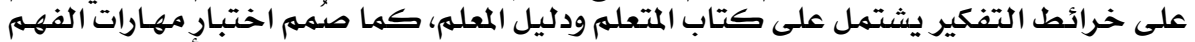

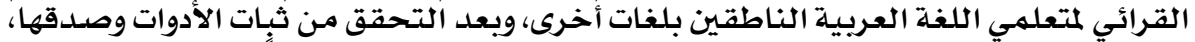

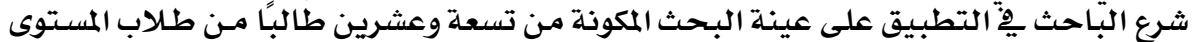

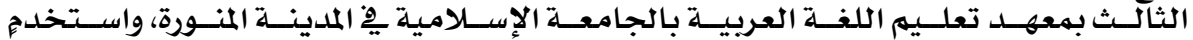

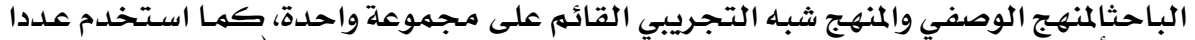

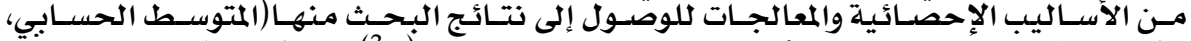

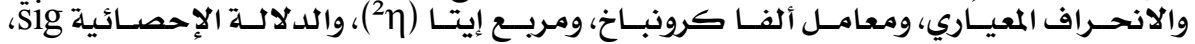

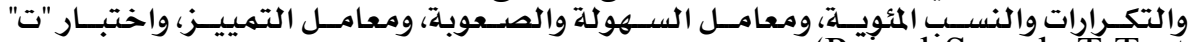

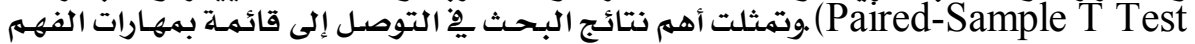

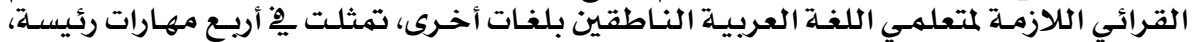

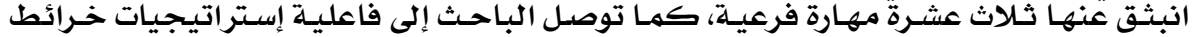

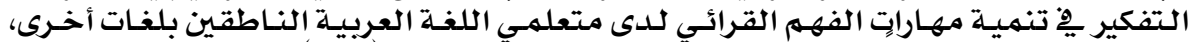

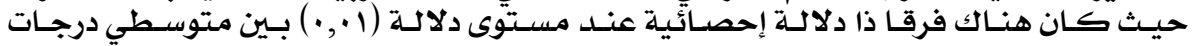

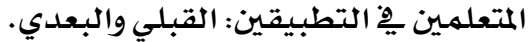

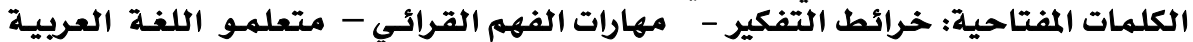
الناطقون بلغات أخرى.

The Effectiveness of a Program Based on Thinking Maps in Developing the Skills of Reading Comprehension Skills Among Learners of Arabic Speakers in Other Languages Bader Hudayban Helal al-Harbi

Abstract:

The aim of this research is to measuring the effectiveness of a program based on the strategies of thinking maps in developing reading comprehension skills among Arabic language learners Speakers in other languages. To achieve this, a set of tools was developed: In the teaching of reading comprehension skills, based on thinking maps that includes the learner's book and the teacher's guide. He also designed the test of reading comprehension skills for learners of Arabic speakers in other languages. After checking the validity of the instruments and verifying them, The researcher used the descriptive approach and the semi-empirical approach based on one group. He also used a number of statistical methods and treatments to reach the results of the research (arithmetic mean, standard 
deviation, alpha coefficient) Kronbach, Eta square $\left(\eta^{2}\right)$, statistical significance sig, repetitions and percentages, coefficient of ease and difficulty, coefficient of discrimination, and Pailed-Sample T Test.The most important results of the research were to reach a list of reading comprehension skills necessary for learners of Arabic speakers in other languages, represented in four main skills, which resulted in thirteen sub-skills. The researcher also found the effectiveness of strategies of thinking maps in developing reading comprehension skills among Arabic speaking In other languages, where there was a significant difference at the level of (0.01) between the average grades of learners in the applications: tribal and remote.

Keywords: Thinking Maps - Reading comprehension skills - Arabic speakers in other languages.

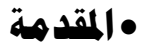

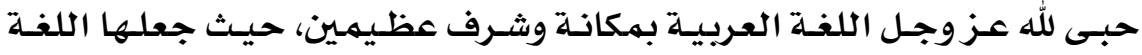

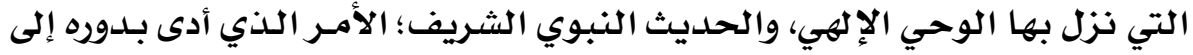

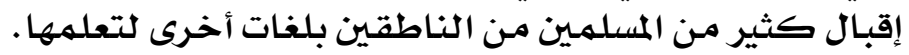

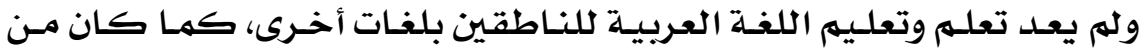

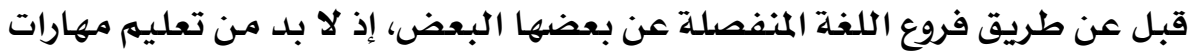

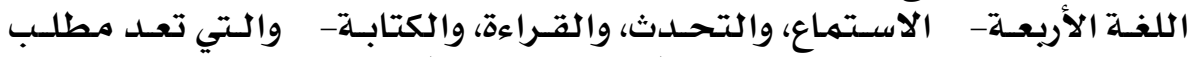

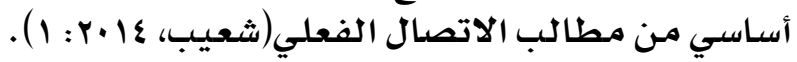

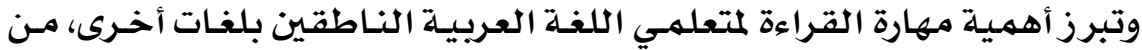

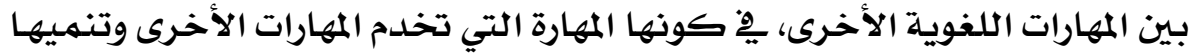

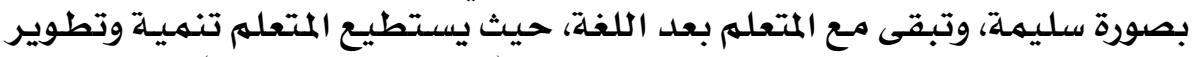

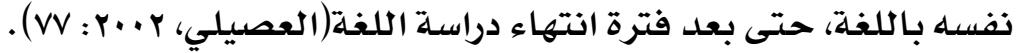

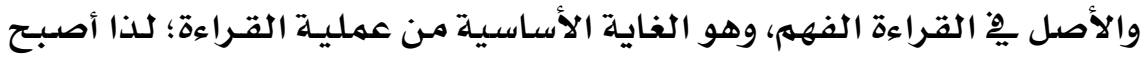

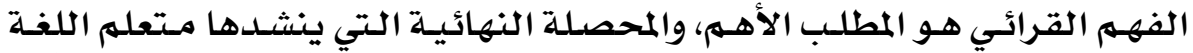

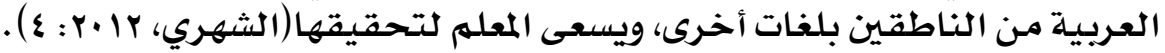

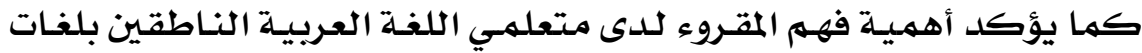

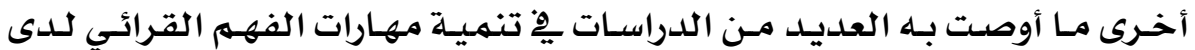

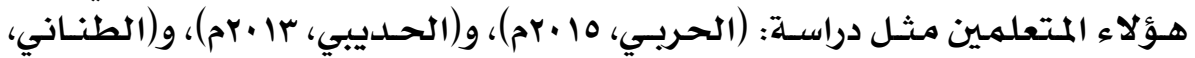

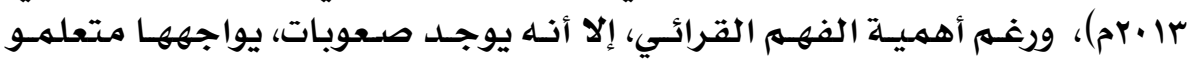

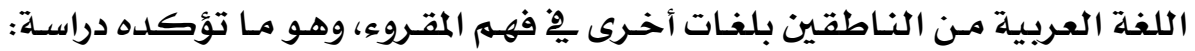

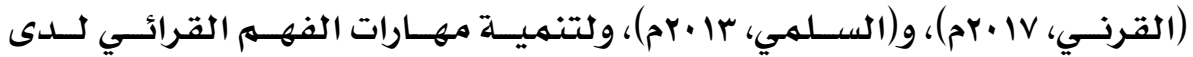

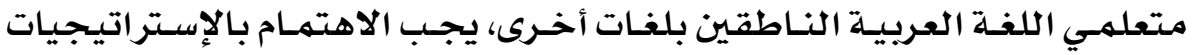

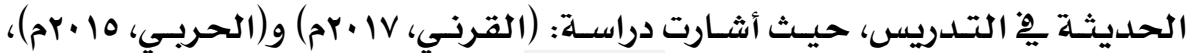




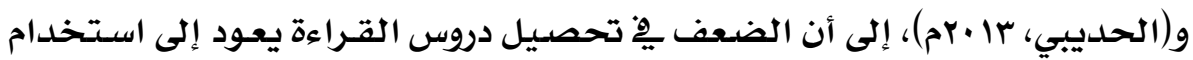

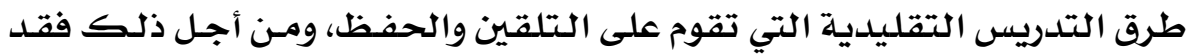

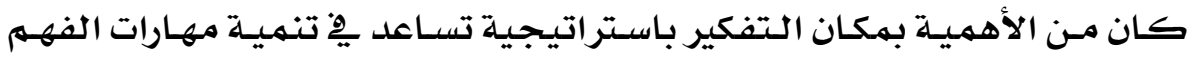

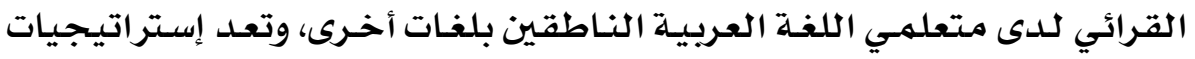

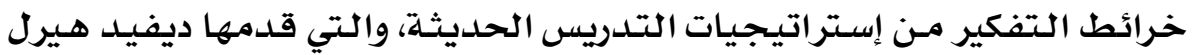

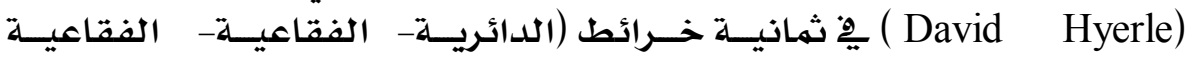

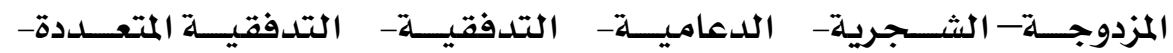

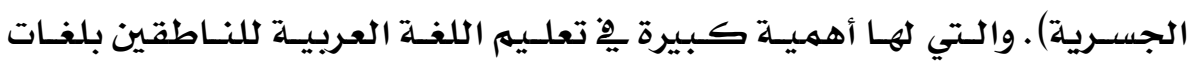

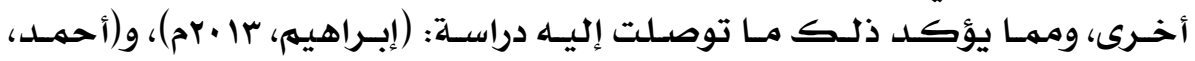

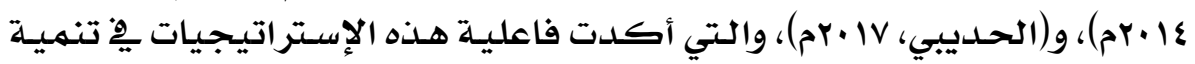

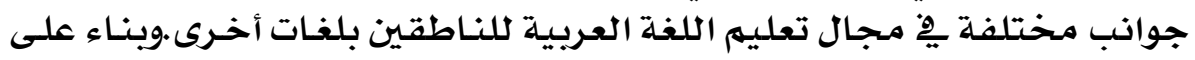

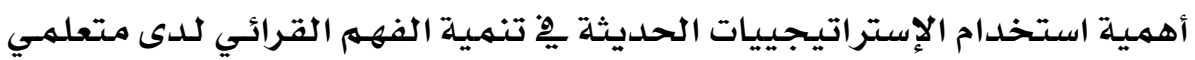

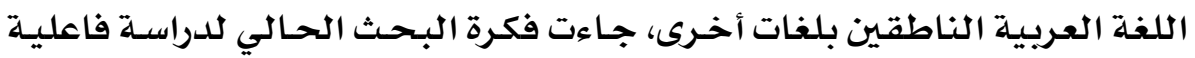

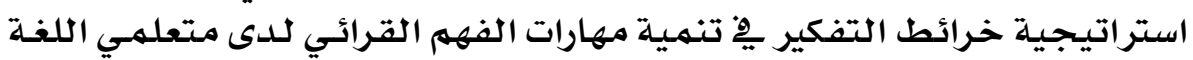
العربية الناطقين بلغات أخرات أخرى.

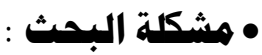

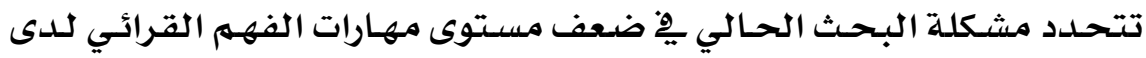

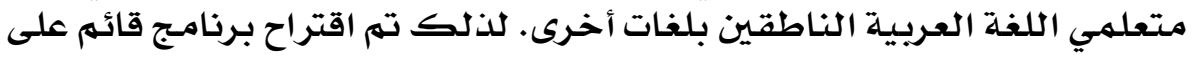

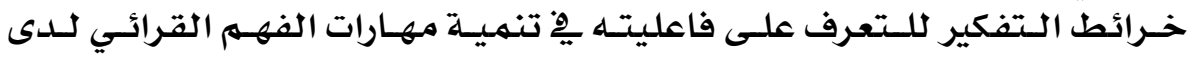

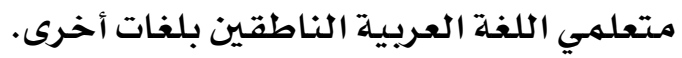

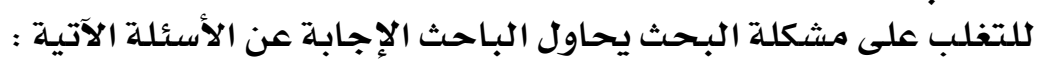

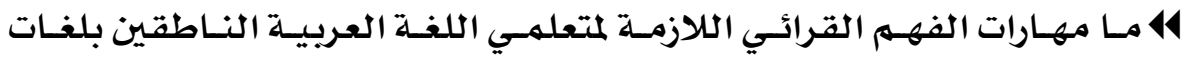

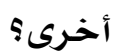
14 مـا مـدى تـوافر مهارات الفهـم القرائي لـدى متعلهـي اللغـة العـربيـة النـاطقين

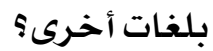

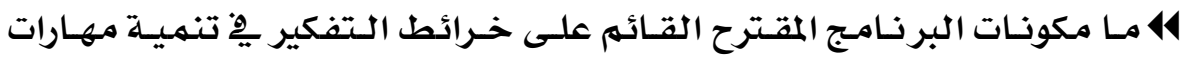

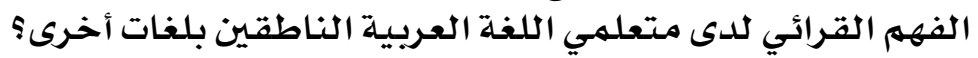

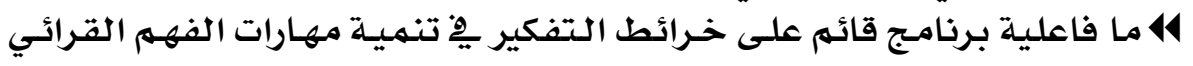

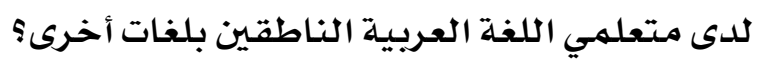

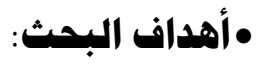
ويهكن تحديد أهداف البحثث يِّ الآتي: 


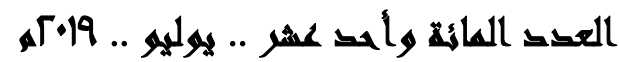

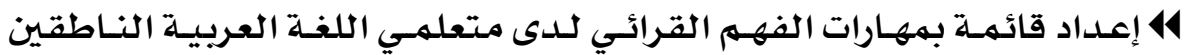
بلغات أخرى. 41 قياس ملدى توافر مهارات الفهم القرائي لدى متعلهمي اللغة العربية النـاطقين بلغات أخرى فياس مدى تواد

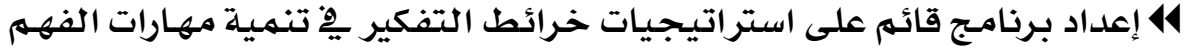

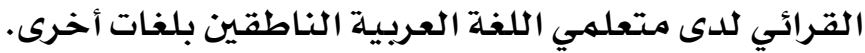

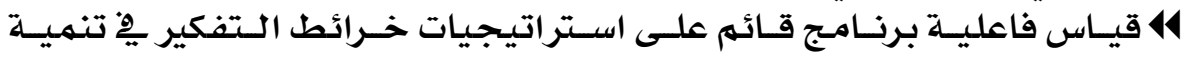

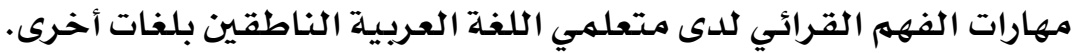

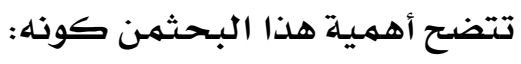

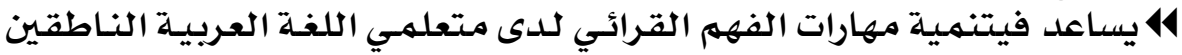

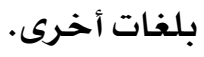

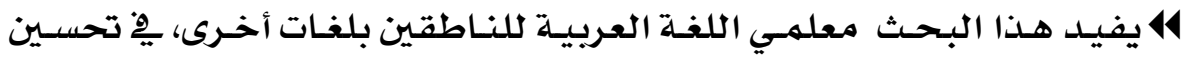

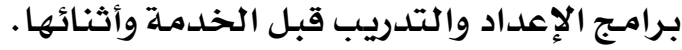

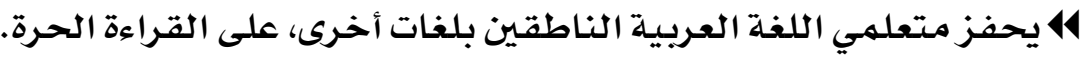

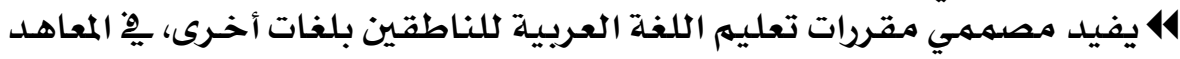
الجامعية أو الخاصدة.

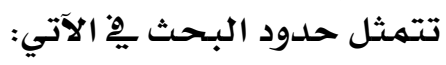

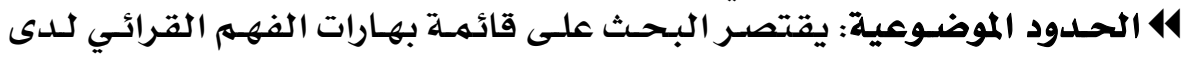

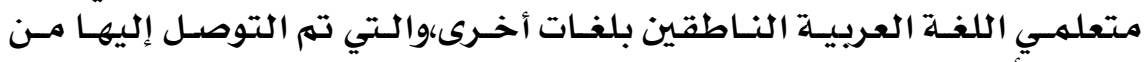

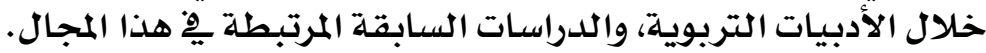

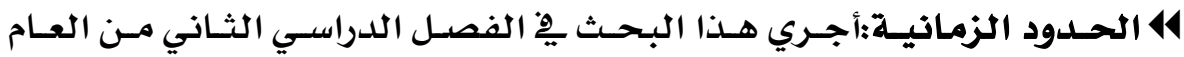

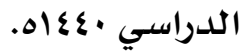

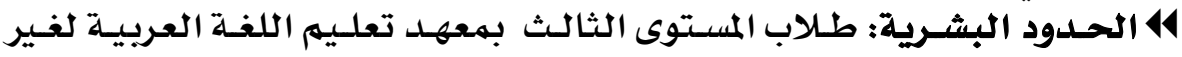

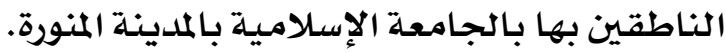

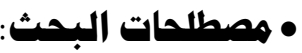

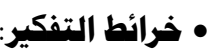

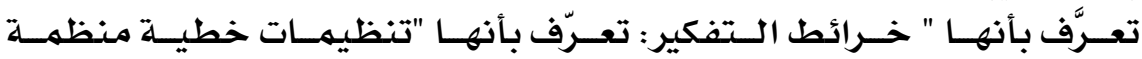

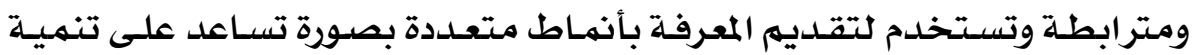

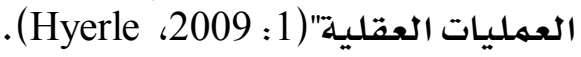

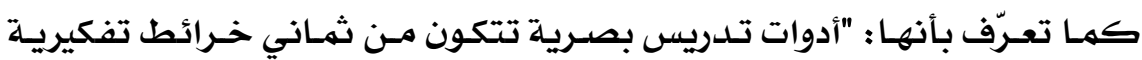

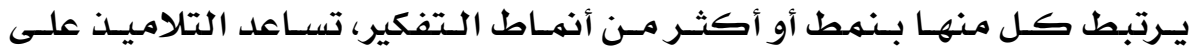




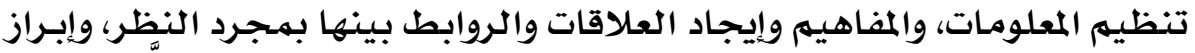

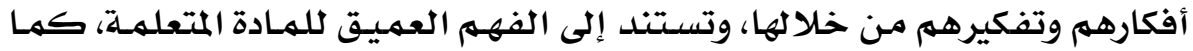

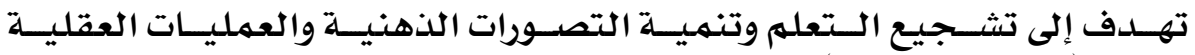

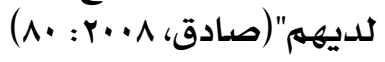

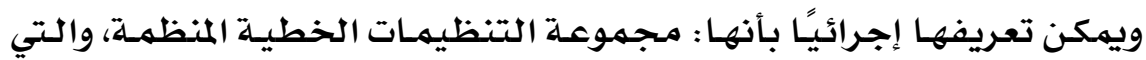

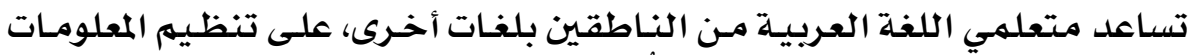

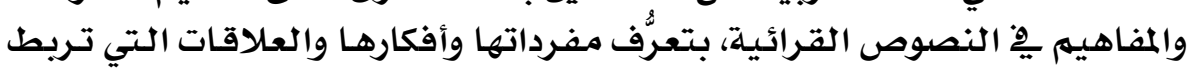

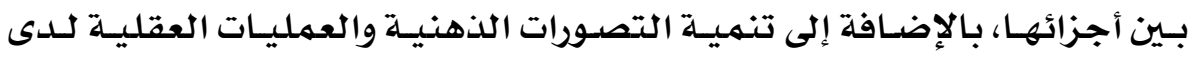
المتعلمـين.

\section{• الفهم القرائي:}

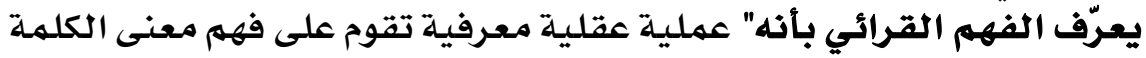

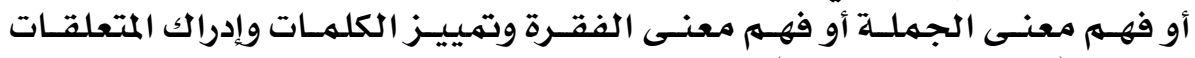

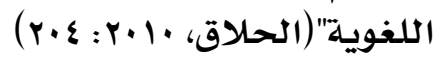

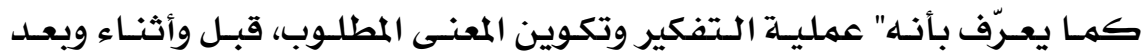

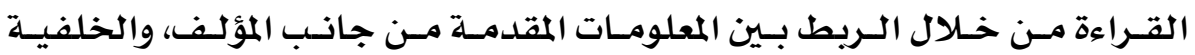

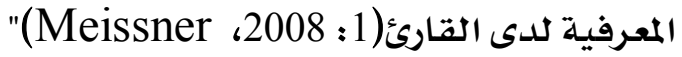

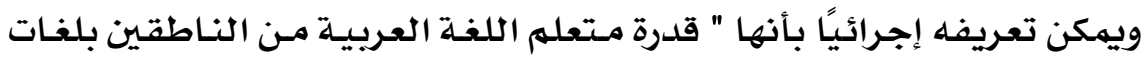

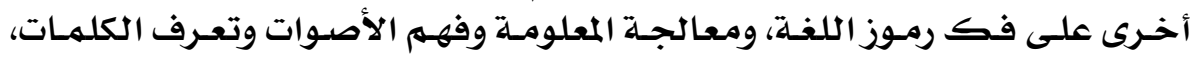

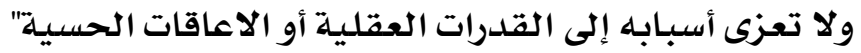

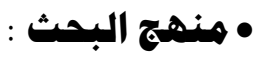

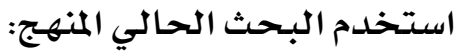

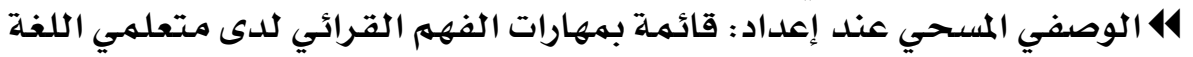

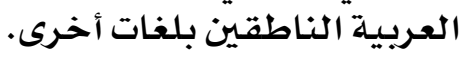

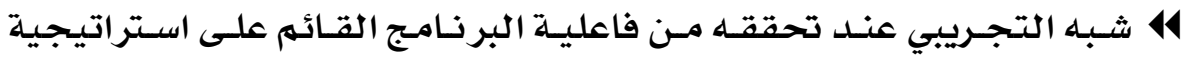

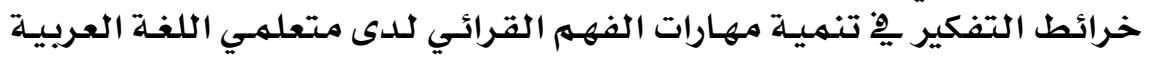
الناطقين بلغات أخرىى.

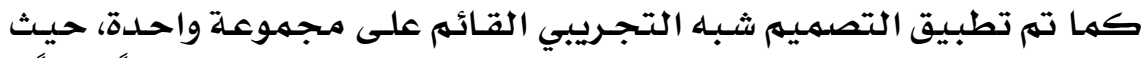

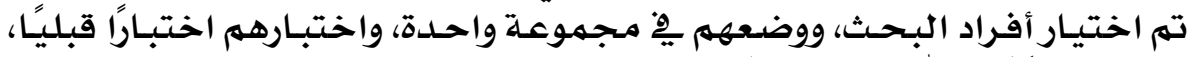

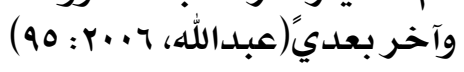

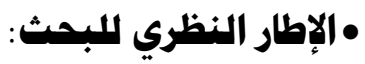

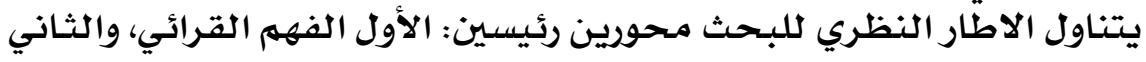
استراتيجية خرائط التفكير. 


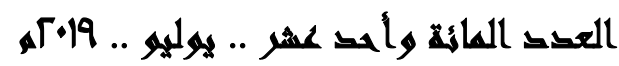

• المحور الأول: الفهم القرائي:

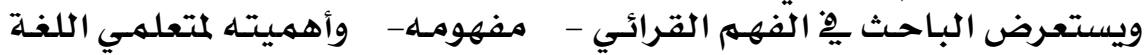

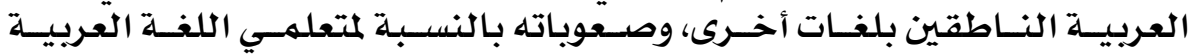

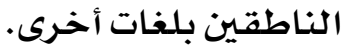

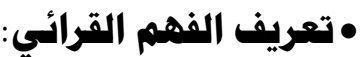

يعرّف الفهه التقراثّي بأنه" عمليـة عقليـة معرفية تقوم على فهم معنى الكلمهة

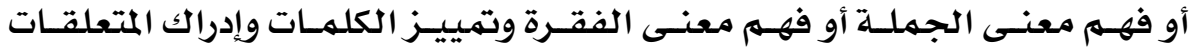

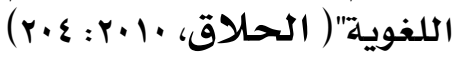

كمـا يعـرّف بأنـه" عمليـة الـتفكير وتكـوين المعنـى المطلـوب، قبـل وأثنـاء وبعـد

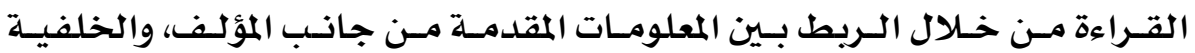

المعرفية لدى القارىئ(40: 2008،

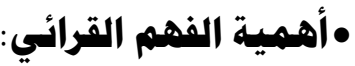

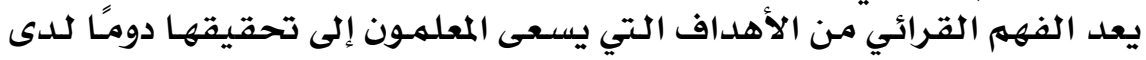

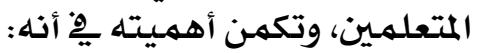

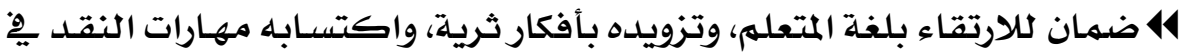

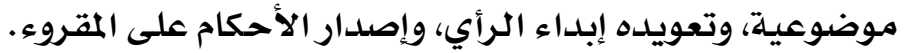

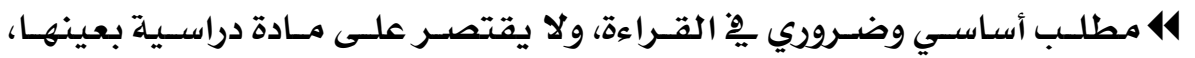
فالفهم يشهل كل كل المواد الدراسيـية.

ها يرتبط بهستويات التفكير العليا .

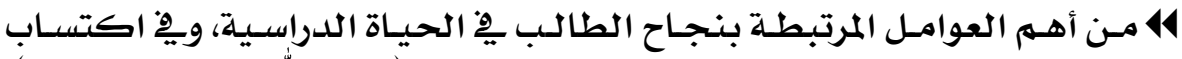

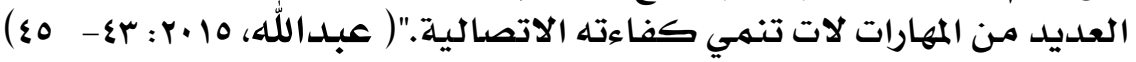

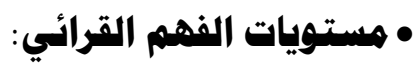

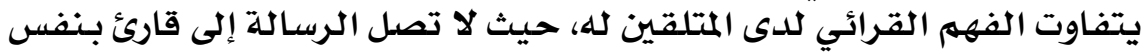

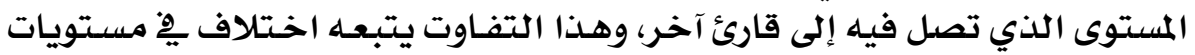

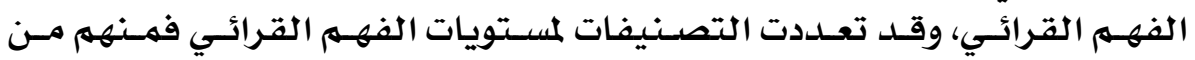
قسهها ثلاثة مستويات وأبرزها تقسيهم طعيمهة و الشعيبي وهي الشي كالآتي:

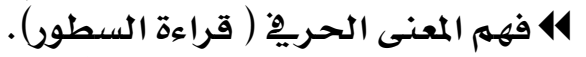

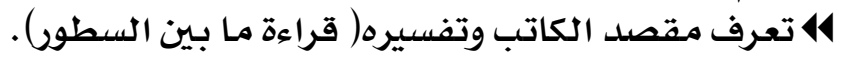

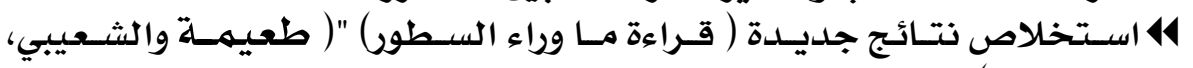
. ( $r \varepsilon \varepsilon: r \cdot$.

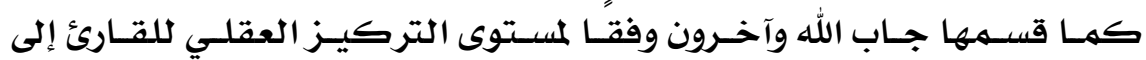

خمسة مستويات كالآتي:

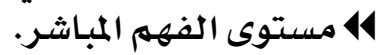

10

1141

دراسات عربية في التربية وعلم النفس (ASEP) 


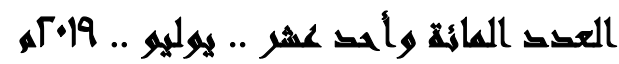

(14 مستوى الفهم الناقد. (14 14 مستوى الفهـم التذوقي.

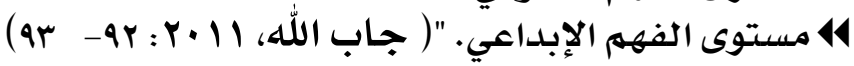

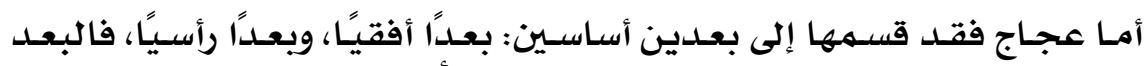

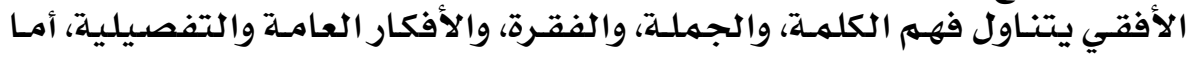

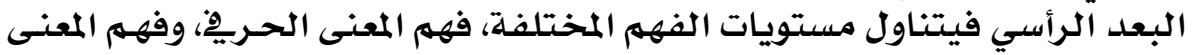

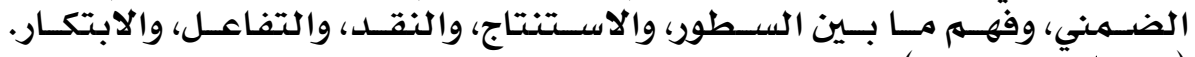

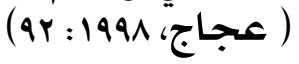

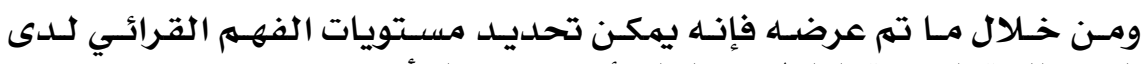

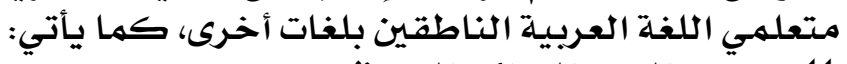
414 مستوى الفهم القرائي الحربِّ: 14 مستوى الفهـ القرائي التفسيري. 14 ال 14 14 مستوى الفهم القرائي التذوقي. • المكونات التفاعلية للفهم القرائي:

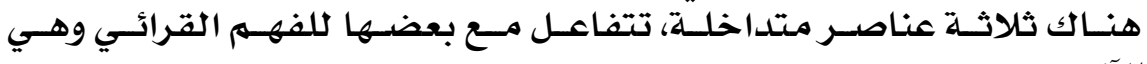

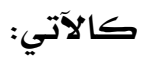

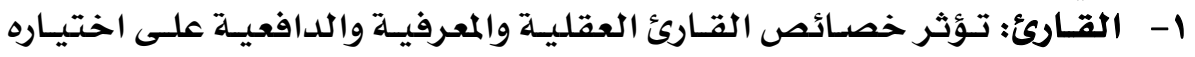

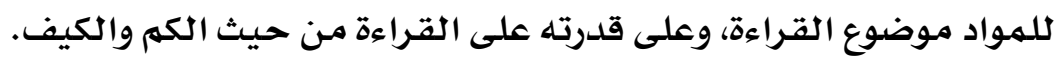

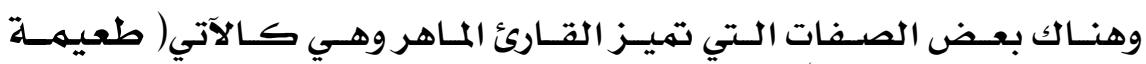

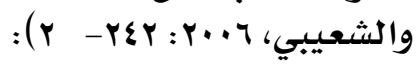
4 القدرةة على سـرعة التعرف على معنى الرمـوز الكتابيـة للغـة العربيـة (كلغـة ثانية). 414 القـدرة على التحكمه فِّ المهارات الأساسية للقراءة بحيث يستخدم مـا يلائم

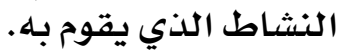

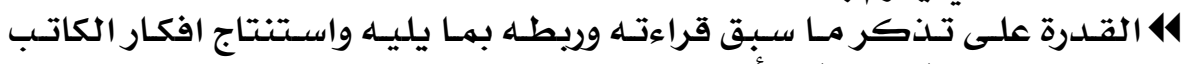

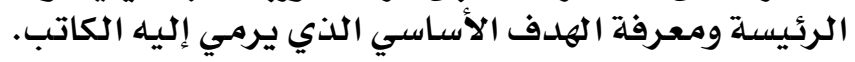
414 القدرة على التركيز والانتباه القوي الميارسية القراءة والاهتهمام بفحوى المادة المقروءة. أضافة إلى ما سبق يرى الباحث أن الثروة اللغوية التي يمتلكها القارئ لها دور بِّ عملية الفهم القرائي.

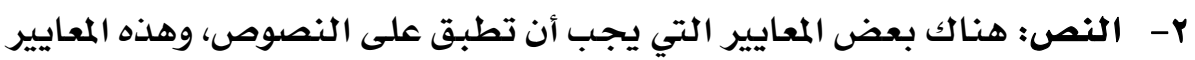

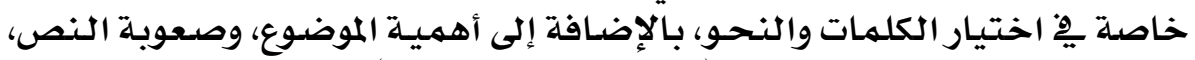

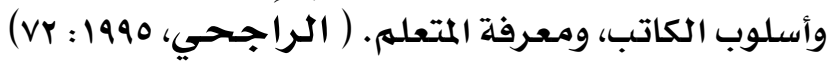

\section{1}




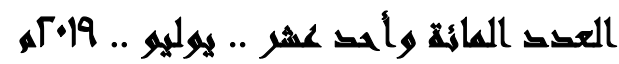

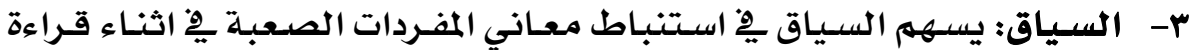

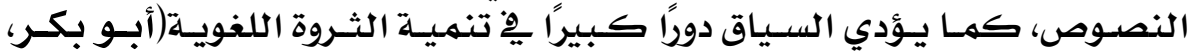

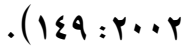

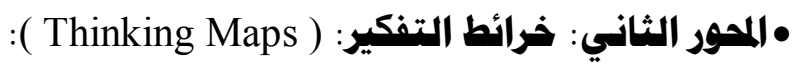

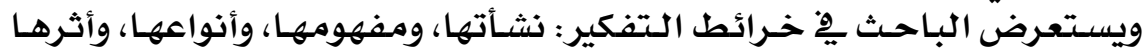
تنمية مهارات الفهم القرائي لدى متعلهي اللغة العربئ العربية الناطقين بلغات أخرى.

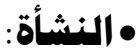

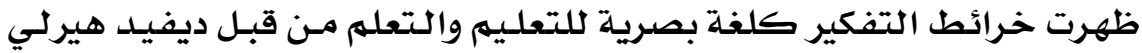

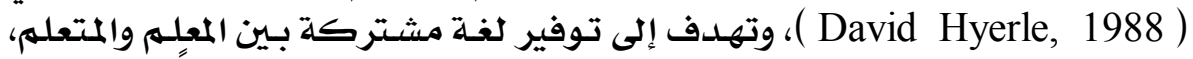

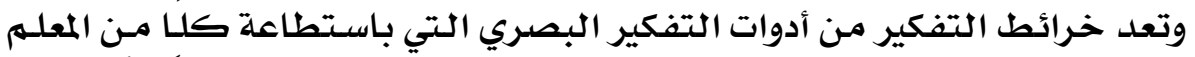

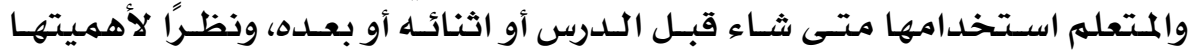

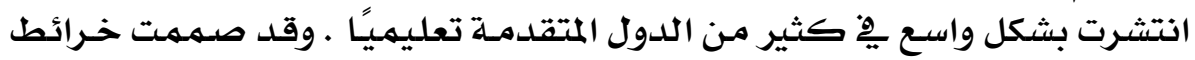

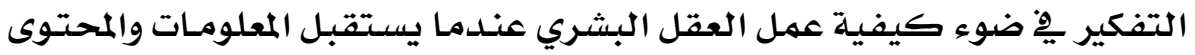

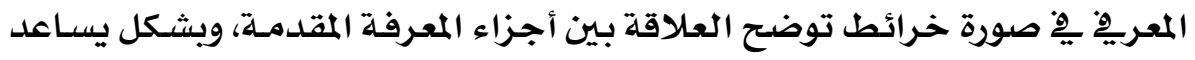

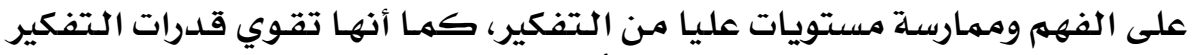

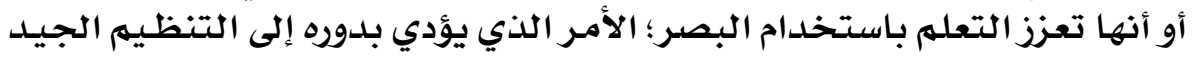

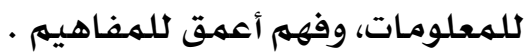

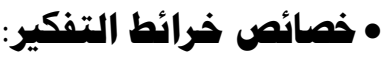

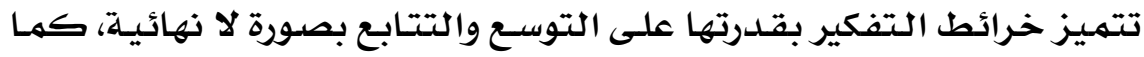

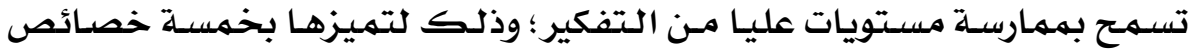

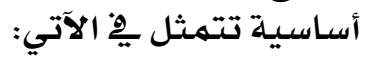

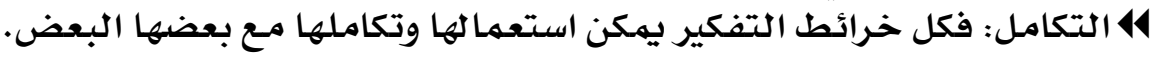

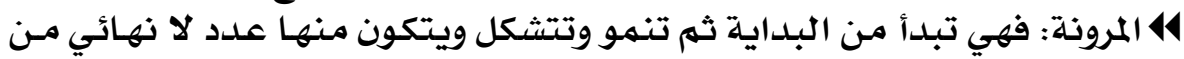

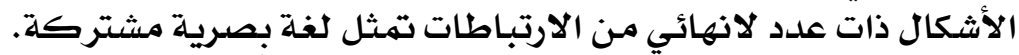

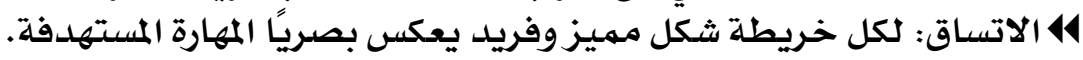

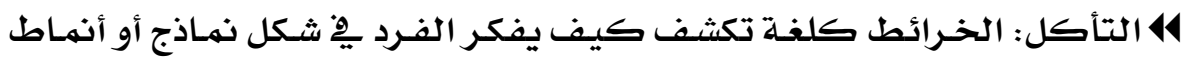

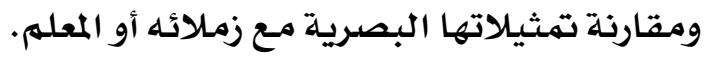

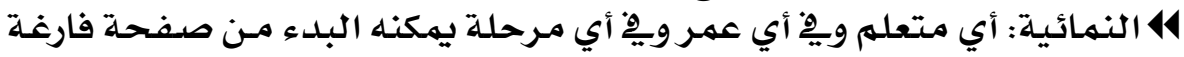

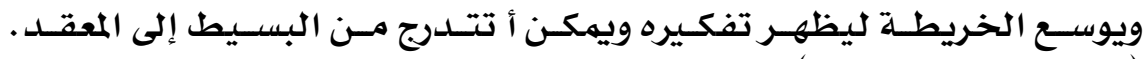

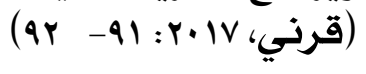

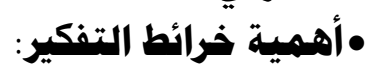

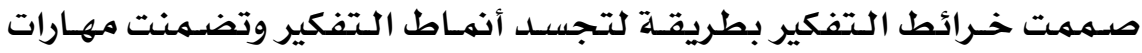

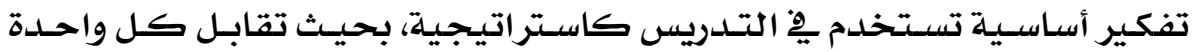




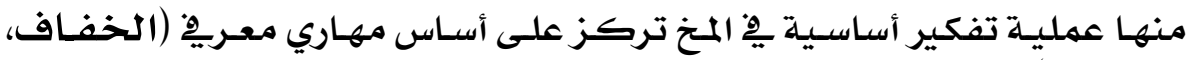
(19\&:r.lV

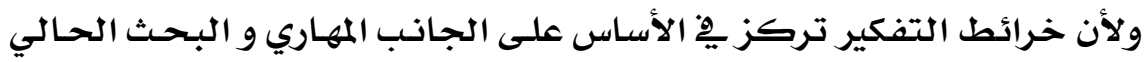

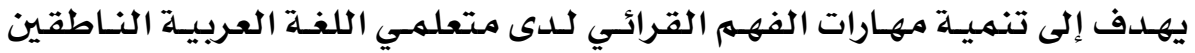

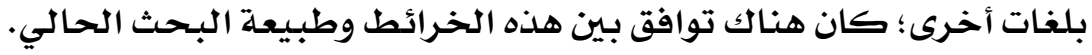
•أنهواع خرائط التفكير: تتكون خرائط التفكير من ثمانية أنواع، لكل نوع شكل واستـخدام محسدد وهي كالآتي: تيكون

•أولا: الخريطة الدائرية Circle Map:

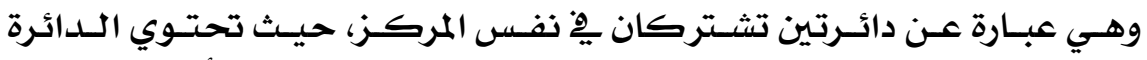

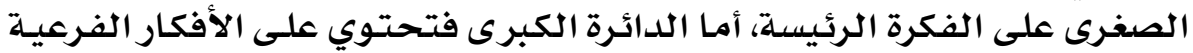

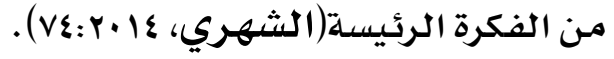

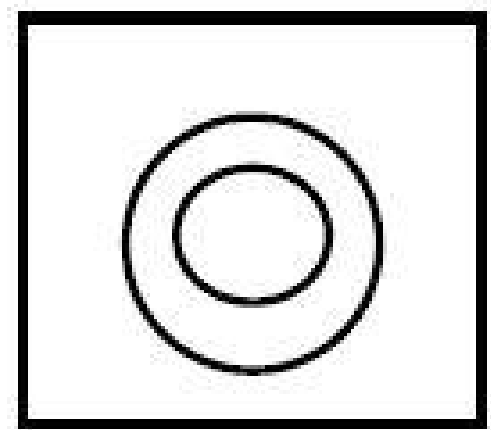

\section{ثكل (1) خريطة التفكير اللائرية}

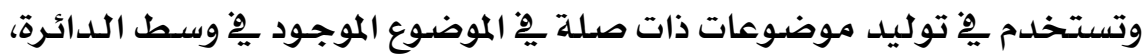

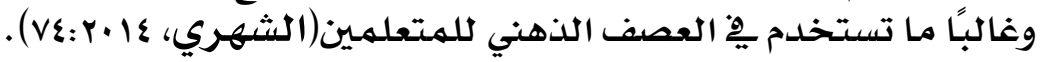

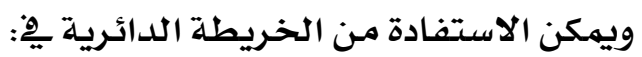

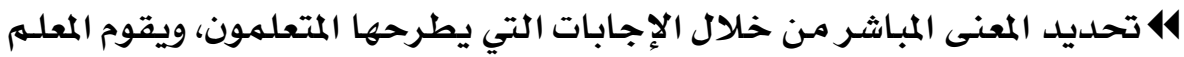

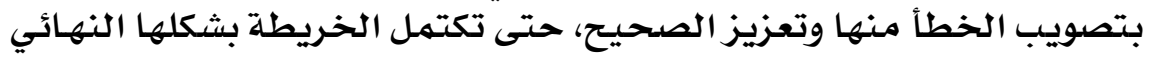

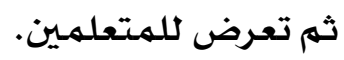

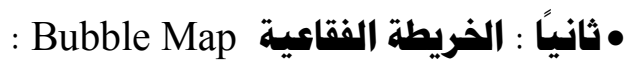

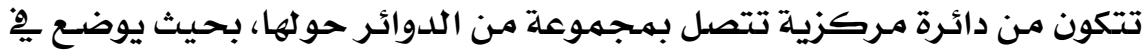

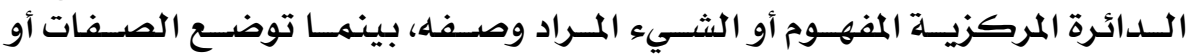

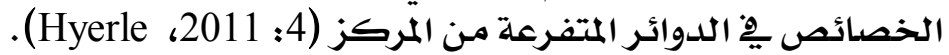




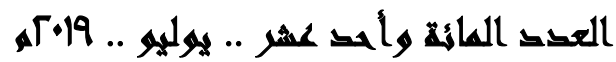

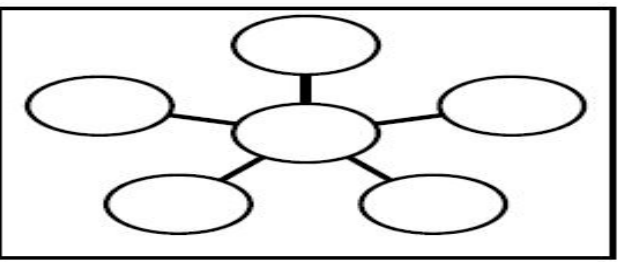

ثكل (r) خريطة التفكير الفقاعية

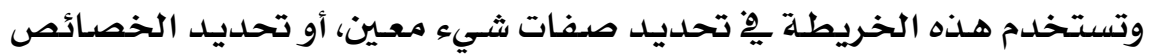
لمفهوم معين.

ويهكن الاستفادة من الخريطة الفقاعيـة فِّ:

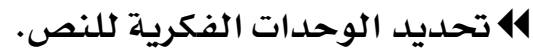

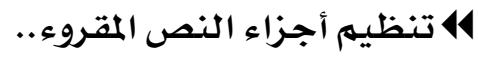

• ثالثًا: الخربطة الفقاوية المزدوبهة Bubble MapDouble: وهي امتداد للخريطة الفقاعيـة، وتتكون مـن دائرتين مـركزيتين متتجـاورتين

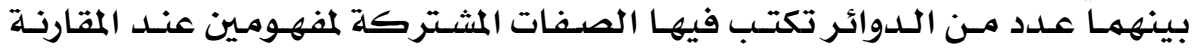

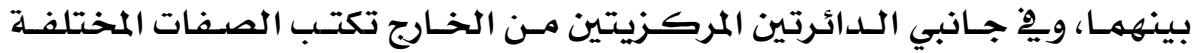

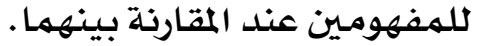

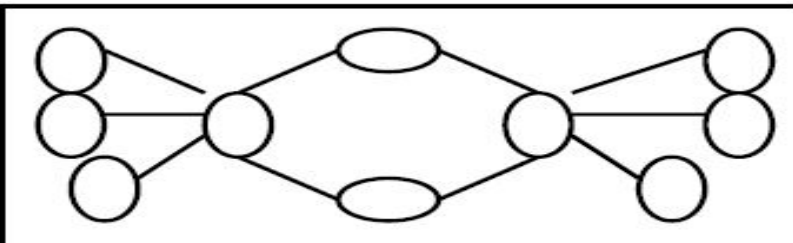

ثكل(r) خريطة التفكير الفقاعية المزدوجة

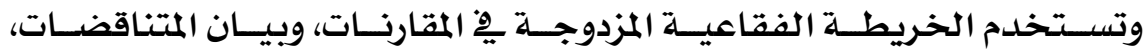

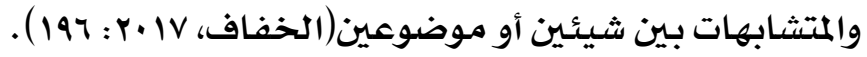

ويهكن الاستفادة من الخريطة الفقاعية المزدوجة يفة:

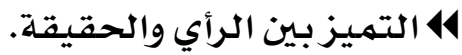
•رابعًا: الخريطة الشمرية Tree Map:

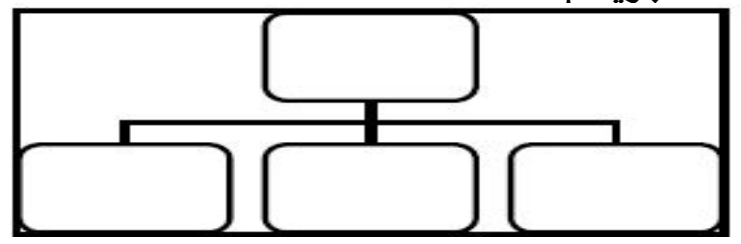

ثكل (ع) خريطة التفكير الشجرية

$10 \varepsilon$ 


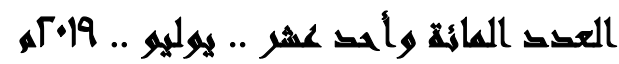

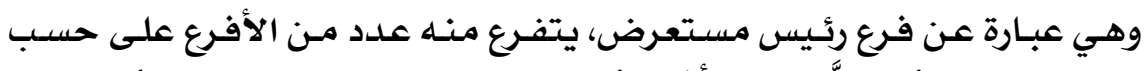

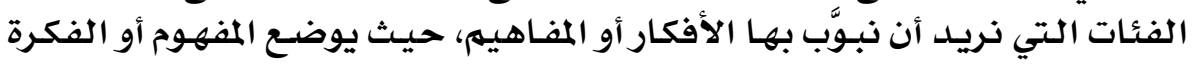

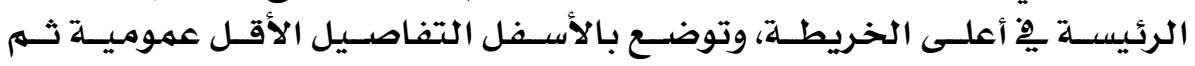
التفاصيل التي تليها وهكذا.

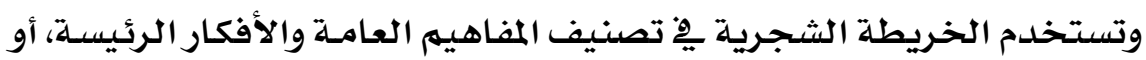

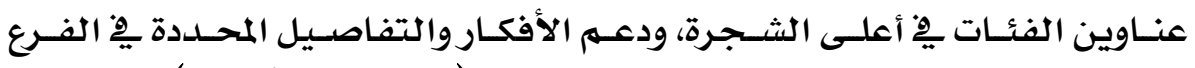

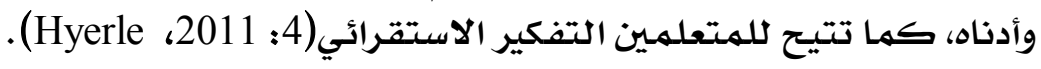

ويمكن الاستفادة من خريطة التفكير الشجرية يِّة:

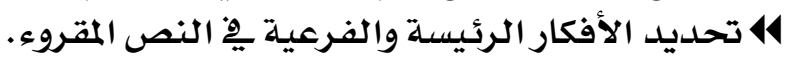

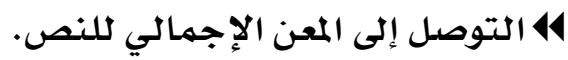

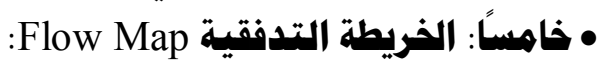

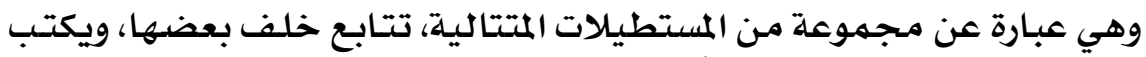

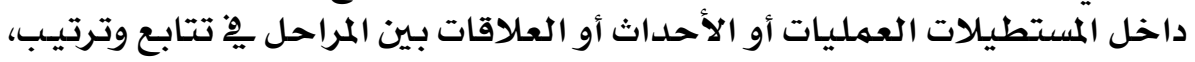

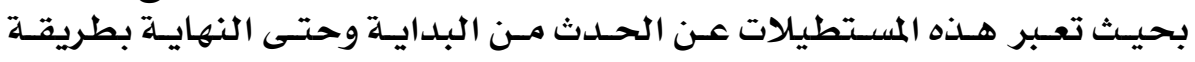
متسلسلة

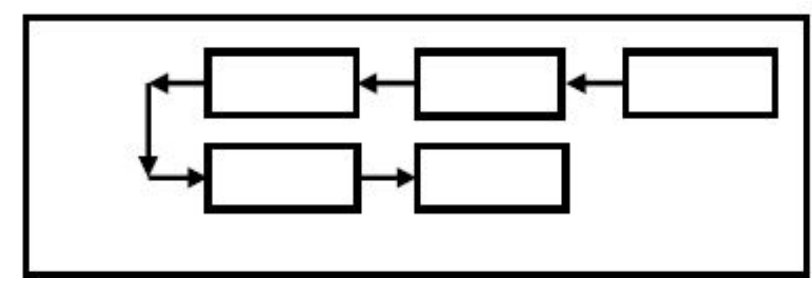

شكل (0) خريطة التفكير التدفقية

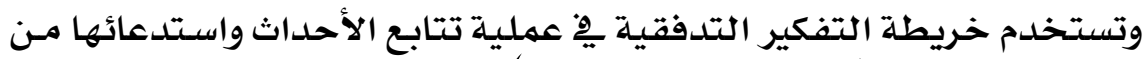

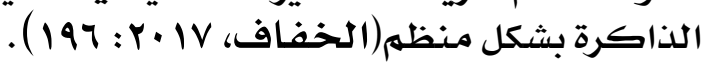
ويمكن الاستفادة من خريطة التفكير التدفقية يِّة:

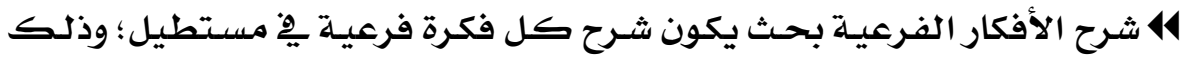

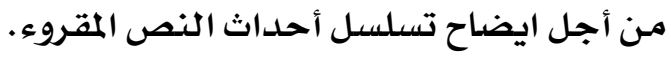

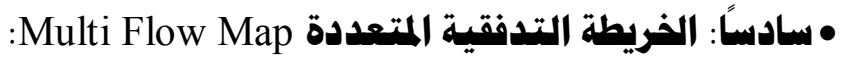

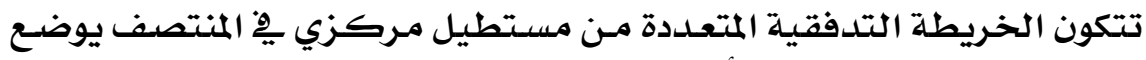

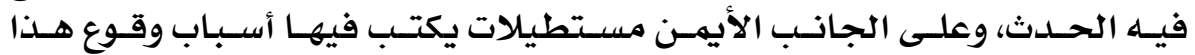

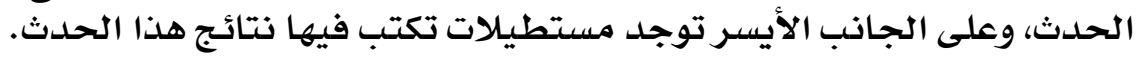


العقى المائه واشت عشر .. يوليو .. 19.5م.

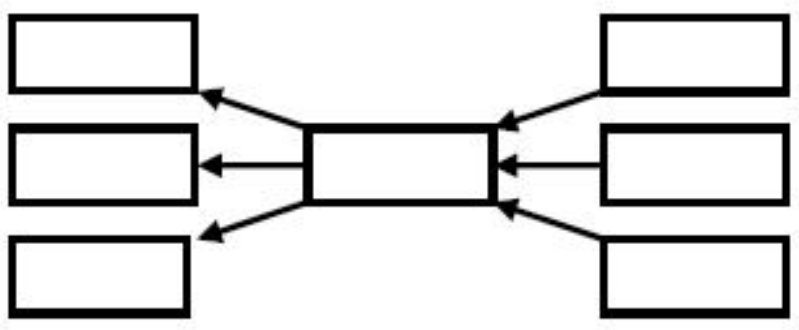

ثكل (7) خريطة التفكير التدفقية المتعلددة

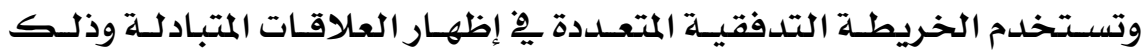

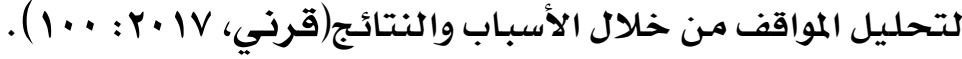

ويهكن الاستفادة من هذه الخريطة يفة

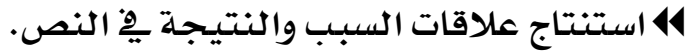

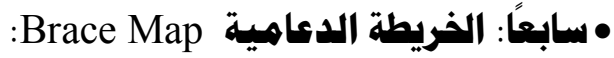

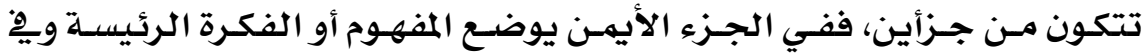

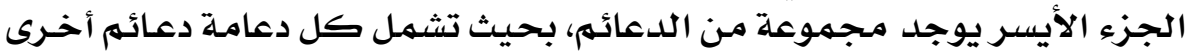

فرعية أكثر تفصيل.

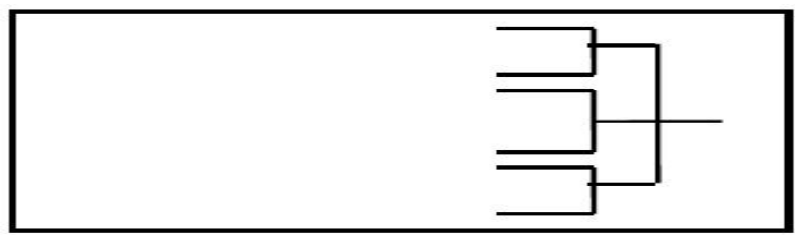

ثكل (v) خريطة التفكير اللهامية

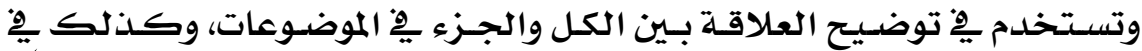

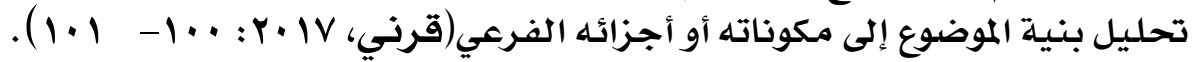

ويمكن الاستفادة من الخريطة الدعامية بِّ:

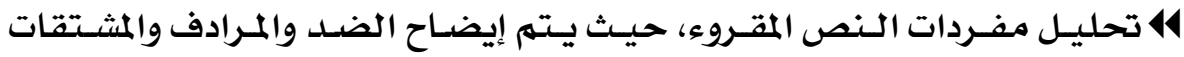

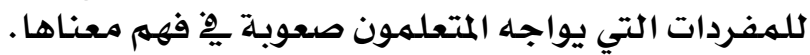

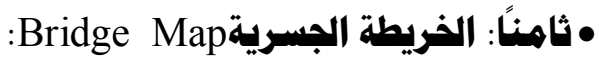

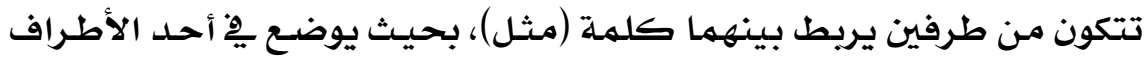

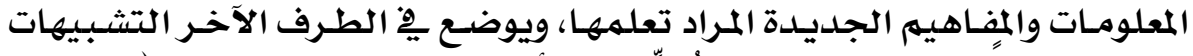

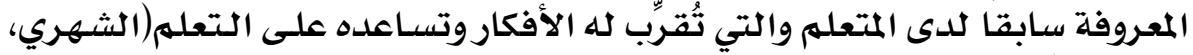

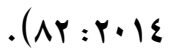




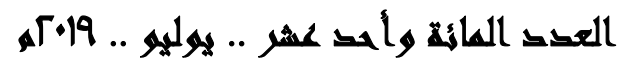

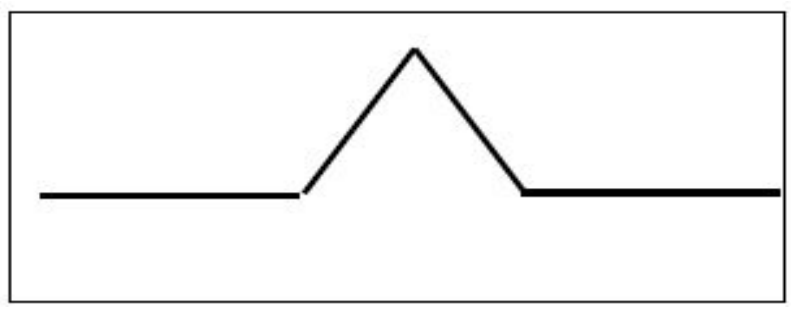

ثكل (1) خريطة التفكير الجسرية

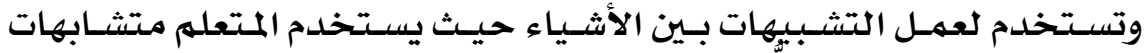

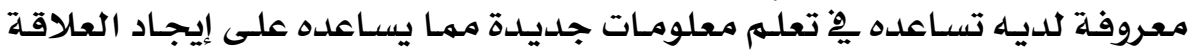

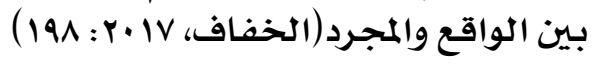

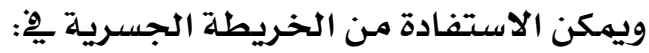

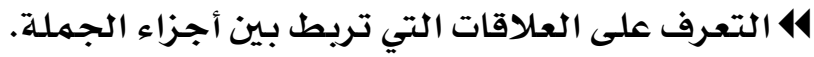

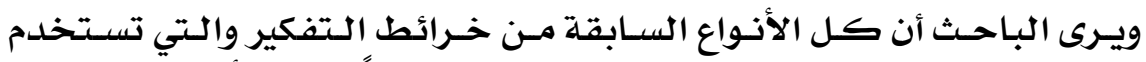

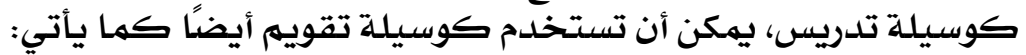

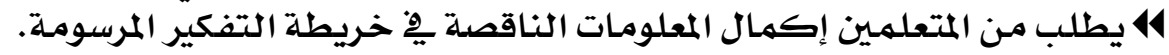

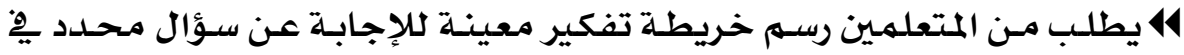
ورقة عمل خارجية.

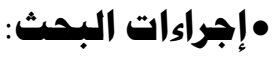

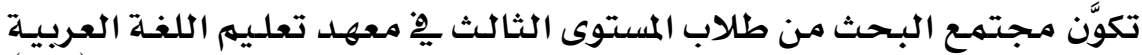

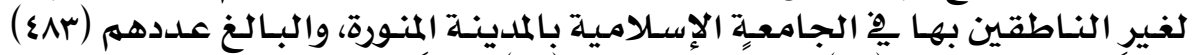

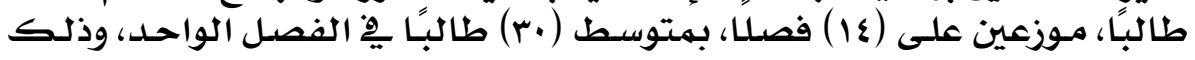

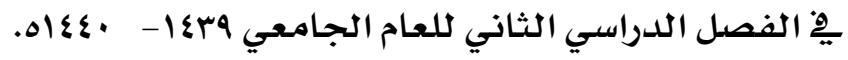

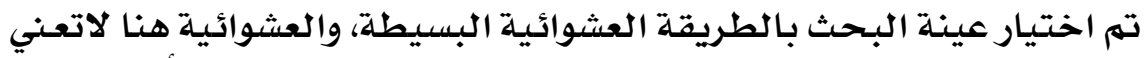

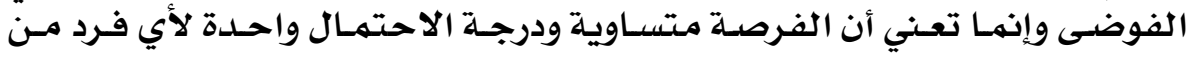

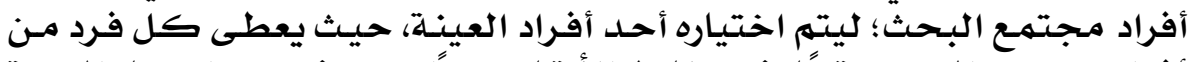

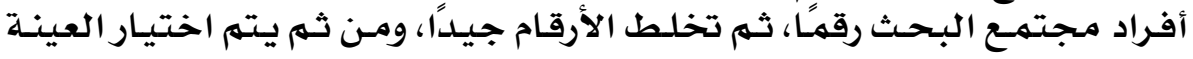

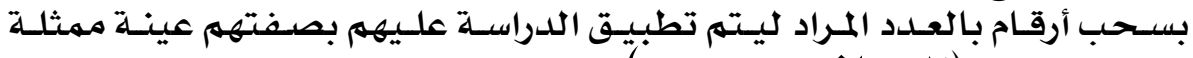

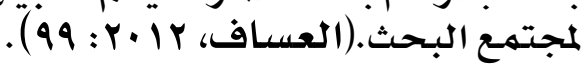

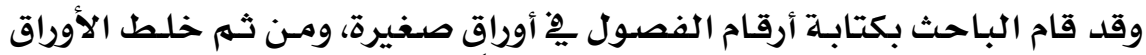

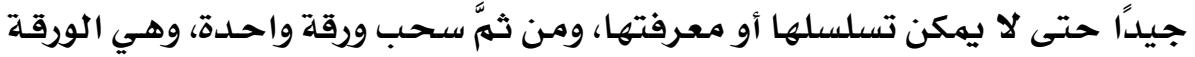

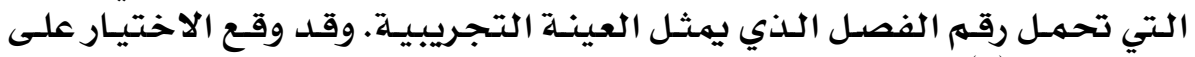

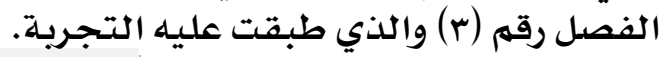




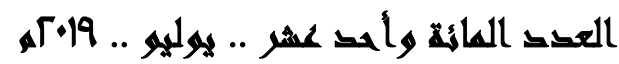

• • - إعداد أدوات البحث وهواده:

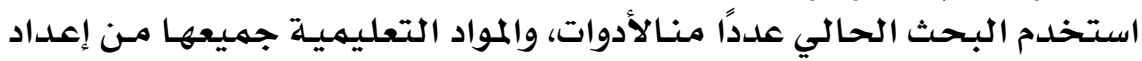

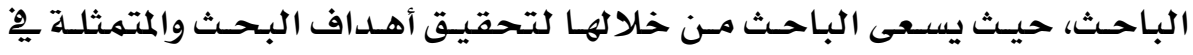

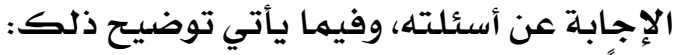

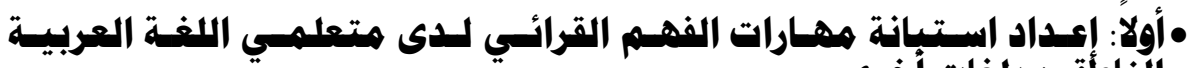

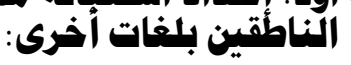

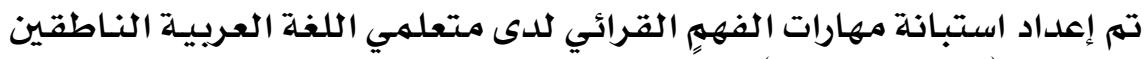
بلغات أخرى (المستوى الثالث) وفقا للخطوات الندات الآتية:

• الهدف هن إعداد الاستبانة.

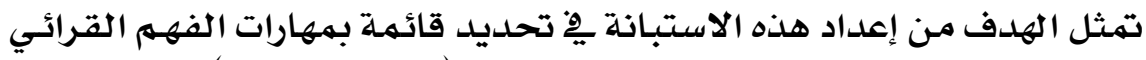
لدى متعلمي اللغة العربية الناطقين بلغات أخرى (المستوى الثالث)

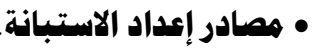

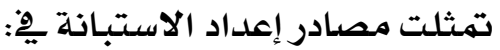

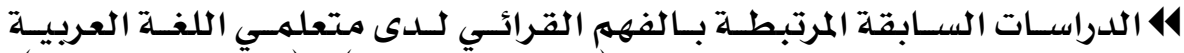

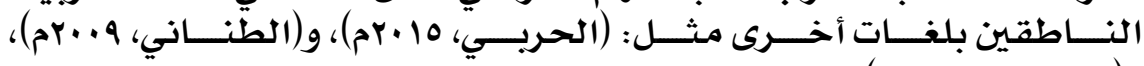

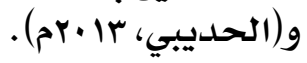

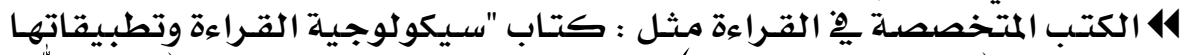

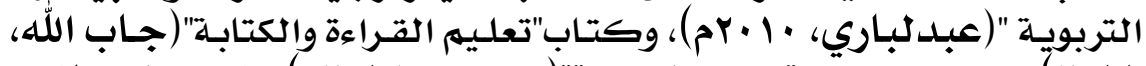

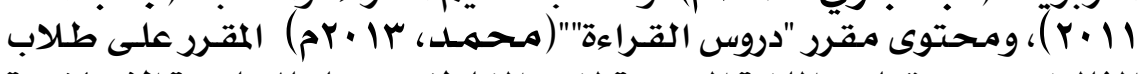

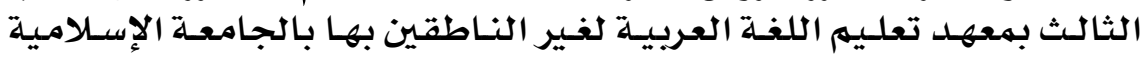

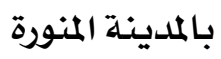

\section{• إعداد الاستبانة في صورتها الأولية.}

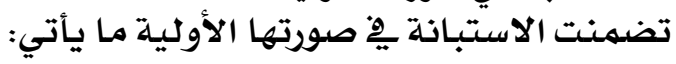

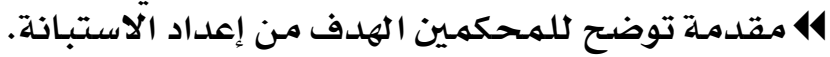

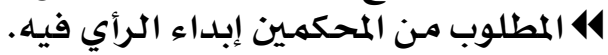

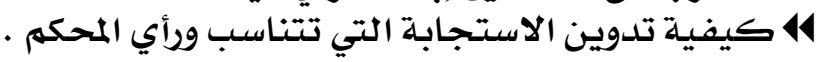
44 التعريف الإجرائي لمهارات الفهمه القرائي.

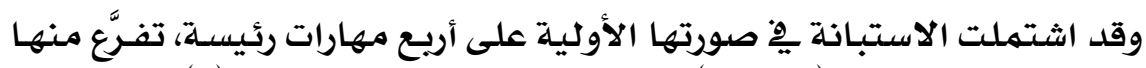

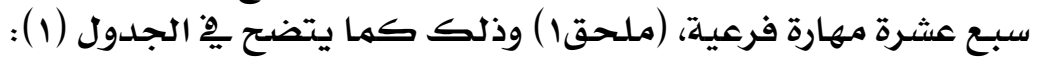

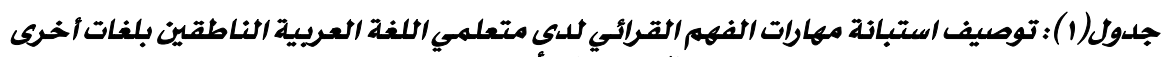

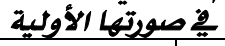

\begin{tabular}{|c|c|c|c|}
\hline النسبت المئويت للمهاراتالفرعيت & عدد المهارات الفرعيت & المهارات الرئيست & م \\
\hline \%rr,rr & 0 & مهارات الفهم القرائى الحريخ & 1 \\
\hline \%.r, & $\varepsilon$ & مهارات الفهم القرائي التفسيري. & $r$ \\
\hline \%.rT,TV & $\varepsilon$ & مهارات الفهم القرائى الناقلد. & $r$ \\
\hline ( & $r$ & مهارات الفهم القرائى التذوقى & $\varepsilon$ \\
\hline \%.... & 10 & $\varepsilon$ & المجموع - المجو \\
\hline
\end{tabular}




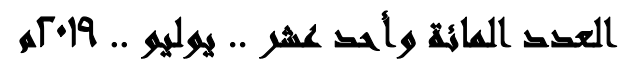

• عرض الاستبانة في صورتها الأولية على المكمين.

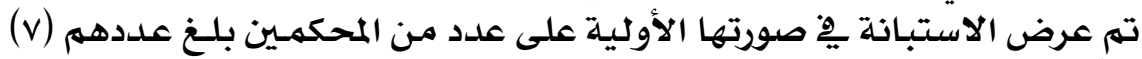

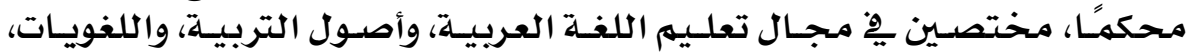

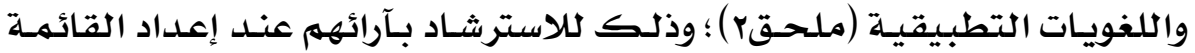

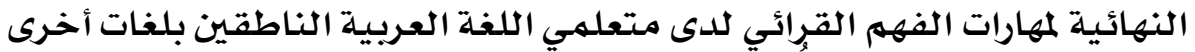

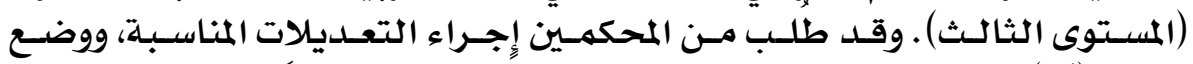

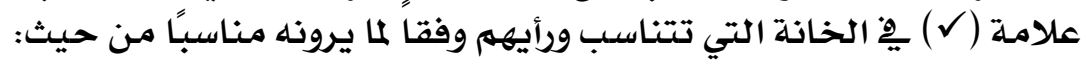

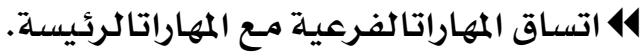

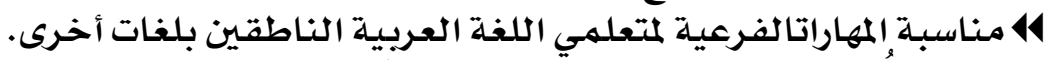

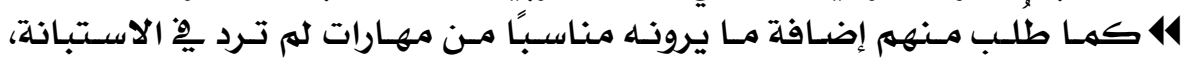

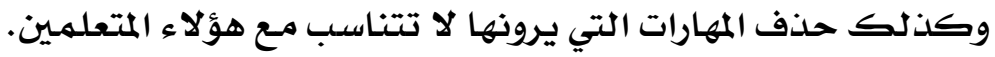

• إعداد قائمة نهائية بمهارات الفهم القرائي.

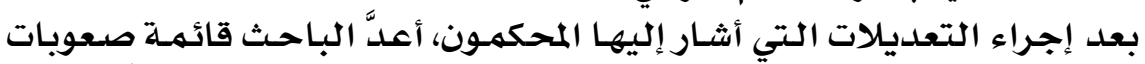

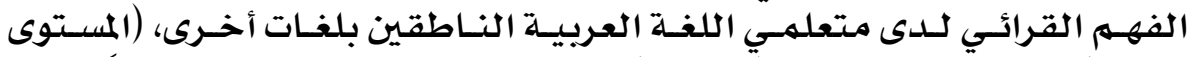

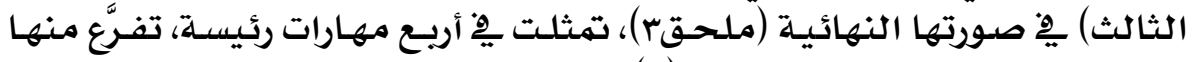

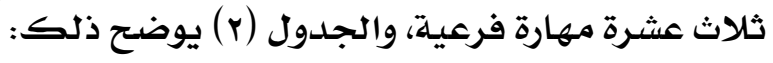

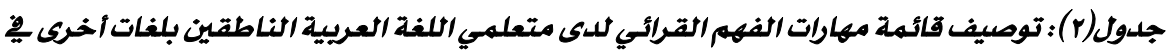
صورتيها النهائية

\begin{tabular}{|c|c|c|c|}
\hline النسبت المئويت للمهاراتالفرعيت & عدد المهارات الفرعيت & المهارات الرئيست & $\hat{n}$ \\
\hline \% ri,ro & 0 & مهارات الفهـم القرائي الحربِ & 1 \\
\hline \%rl,ro & $\varepsilon$ & مهارات الفهـم القرائي التفسيري. & $r$ \\
\hline \% ro,.. & $r$ & مهارات الفهم القرائي الناقد. & $r$ \\
\hline$\%$ & 1 & مهارات الفهم القرائي التذوقي & $\varepsilon$ \\
\hline$\% 1 \ldots, \cdots$ & ir & $\varepsilon$ & المجموع \\
\hline
\end{tabular}

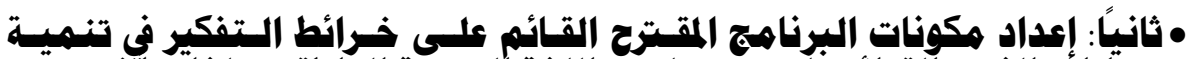

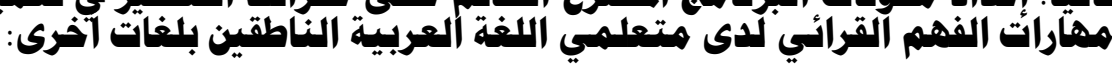

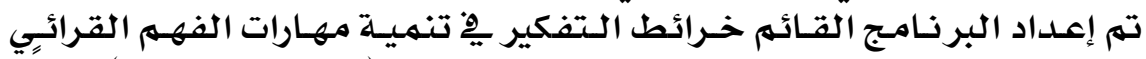

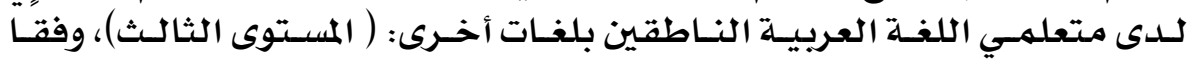

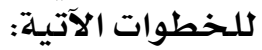

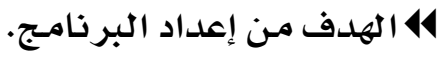

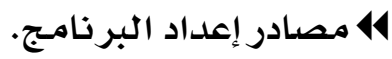

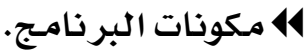

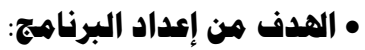

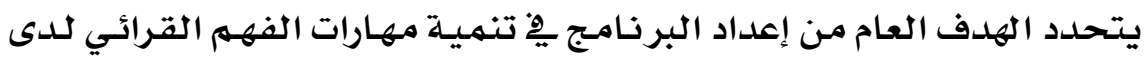

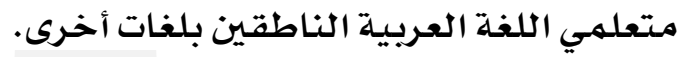




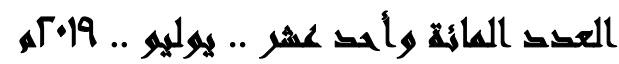

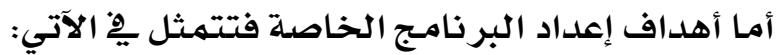

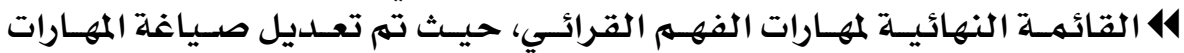

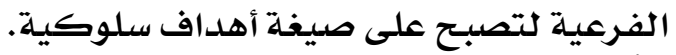

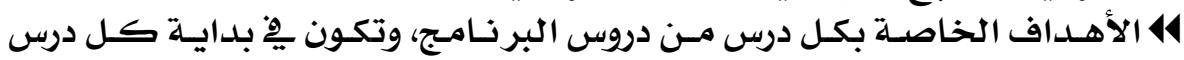
تحت عنوان مخرجات التعلهم.

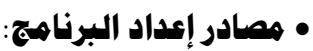

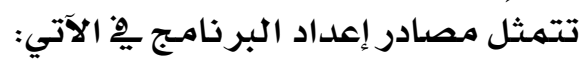

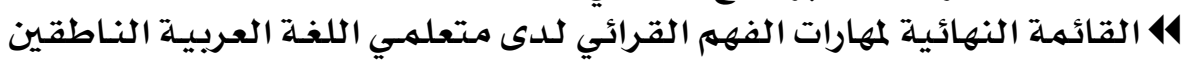
بلغات أخرى.

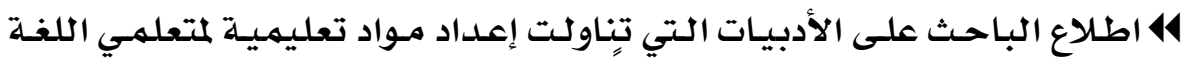

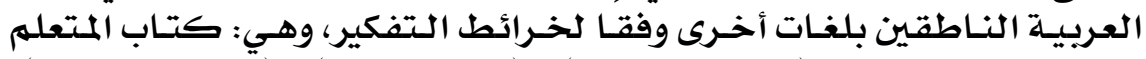

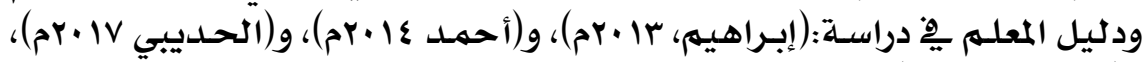

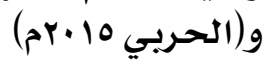

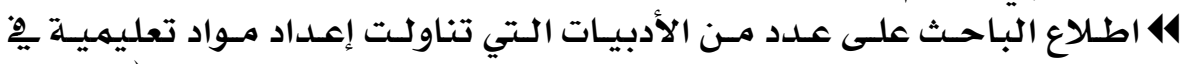

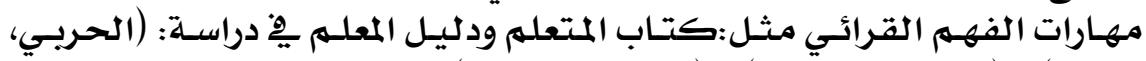

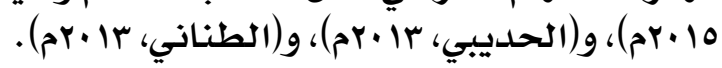

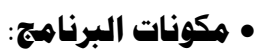

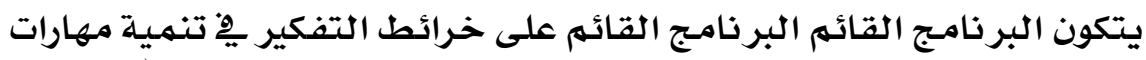

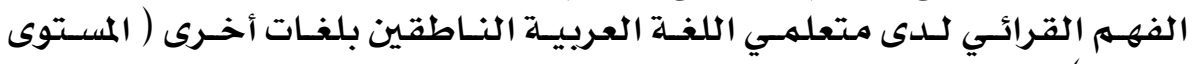

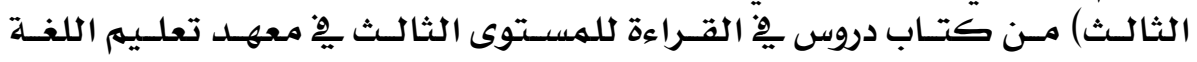

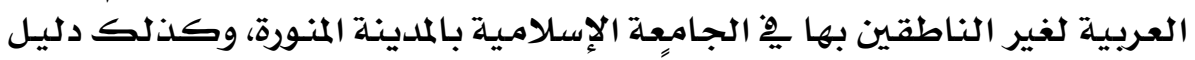

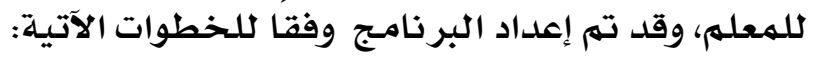

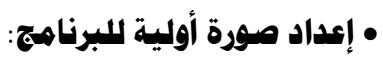
وقد توصل الباحثفي إعداد الصورة الأولية لمكونات البرنامج كمها يأتي:

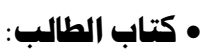

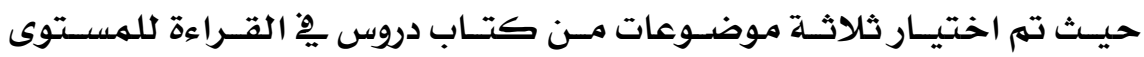

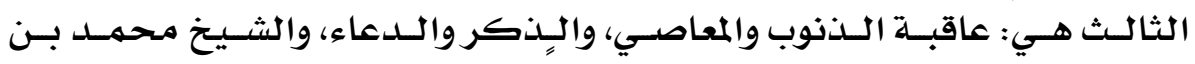

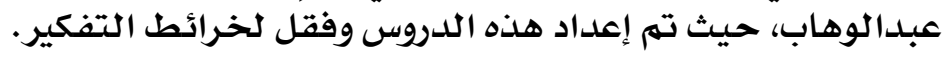

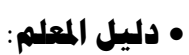

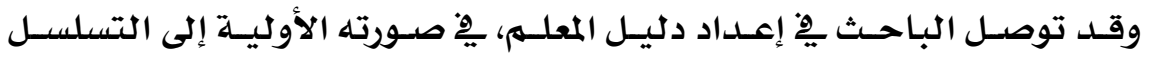
الآتي: ه مقدمـة: تم فيها إعطاء المعلهم نبذة مختصرة عن الدليل ومـا يشـتهل عليـه مـن عناصر.

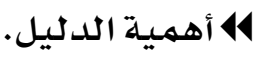




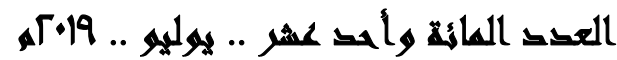

41 الفلسفة التي يقوم عليها الدليل.

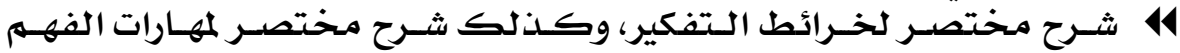
القرائي. 14 مخرجات التعله.

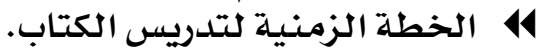

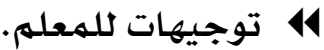

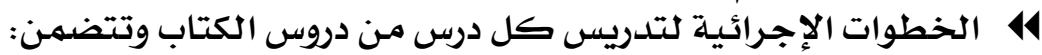
عنوان الدرس.

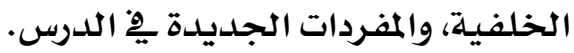

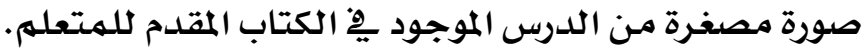

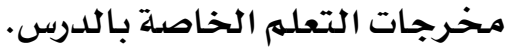

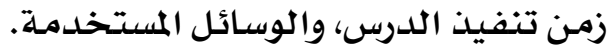
$\checkmark$

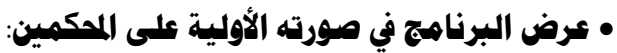

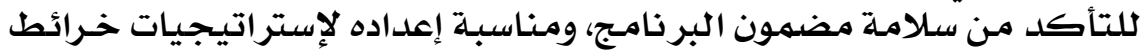

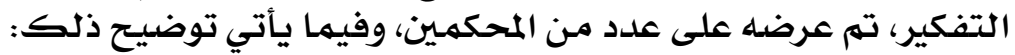
• (ت كتاب الطالب:

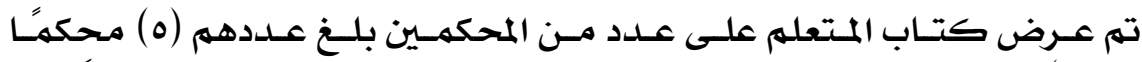

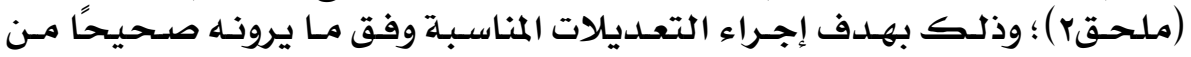

14 مناسـبة الكتـاب لمتعلمـي اللغــة العربيـة النـاطقين بلغــات أخــرى (المسـتوى الثالث).

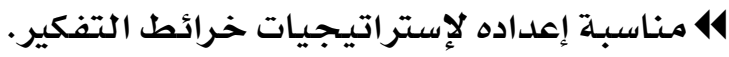

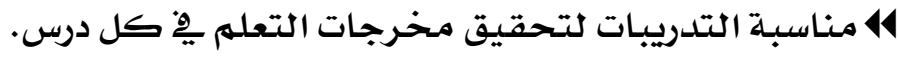
14 صدلاحية الكتاب للتطبيق.

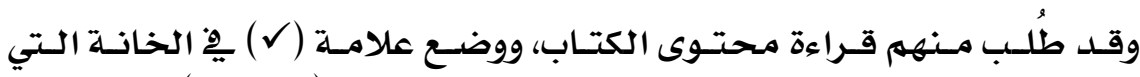

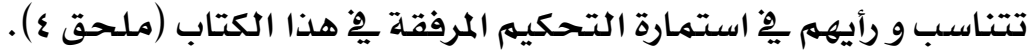

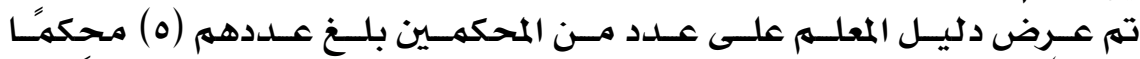

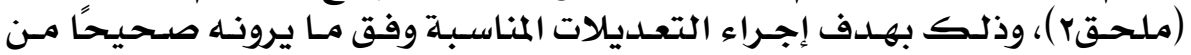

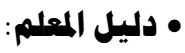
14 سلامهة صياغة مخرجات التعلهم العامة، ومخرجات التحات التعلهم الإجرائية.

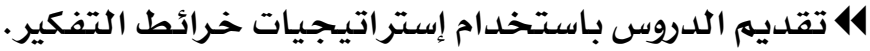

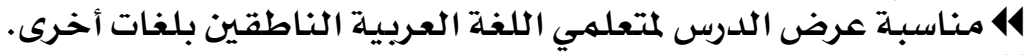

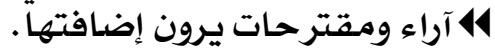




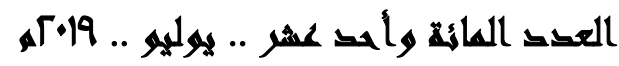

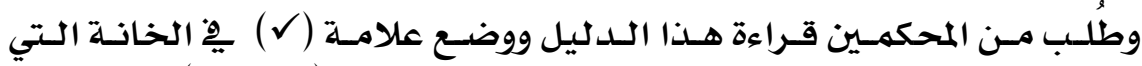

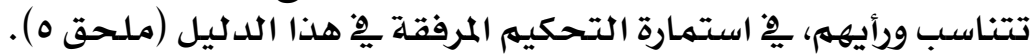

• إجراء التعديلات وصياغة البرناهج في صورته النهائية:

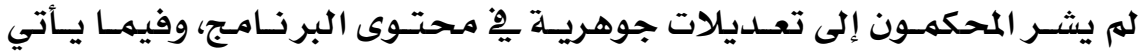

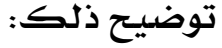

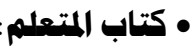

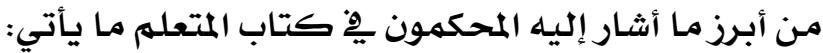

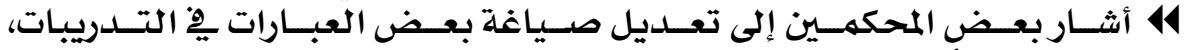

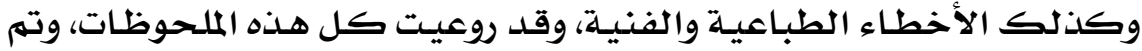
تعديل كتاب المتعلم يُو ضوئها.

وبعد إجراء التعديلات التي أشار إليها المحكمون تمت صياغة كتاب المتعله هِّوِ صورته النهائية ملحق التعل(ج).

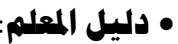

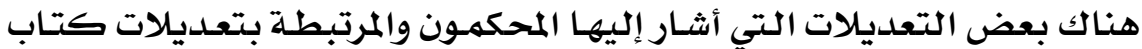

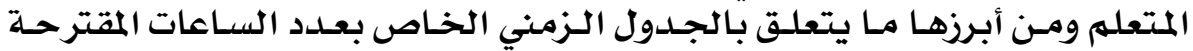

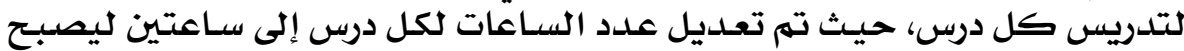

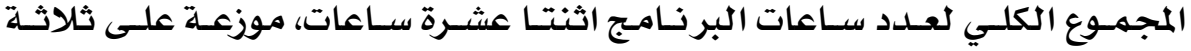

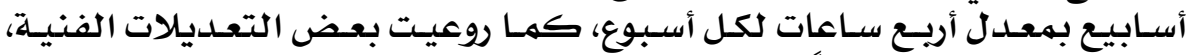
والطباعية يِّ الدليل أيضًا.

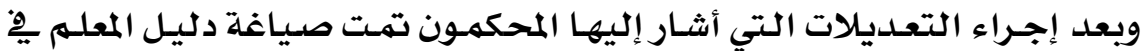

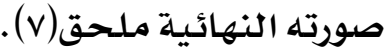

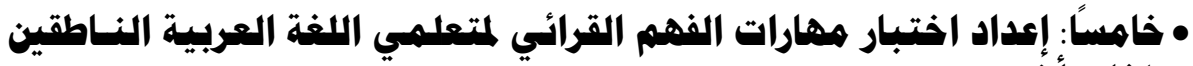

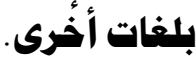

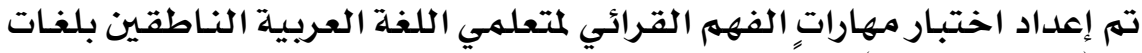
أخرى (المستوى الرابع) وفقا للخطوات الفهات الآتية:

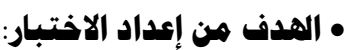

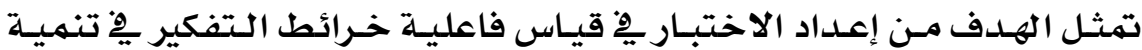

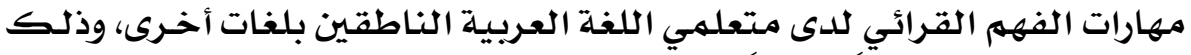

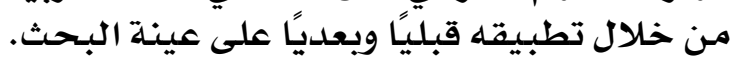

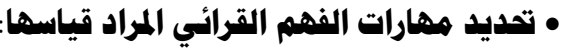

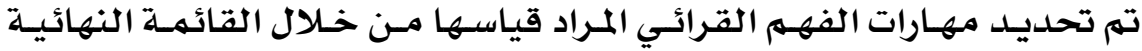

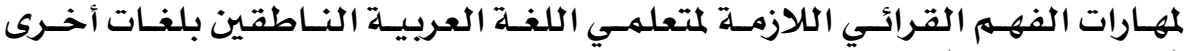
(المستوى الثالث) التي تم التوصل إليها، حيث تم وضع سؤال لكل مهارة إجرائية. 


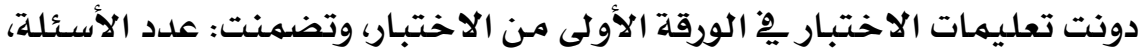

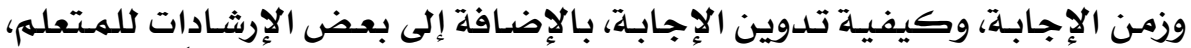

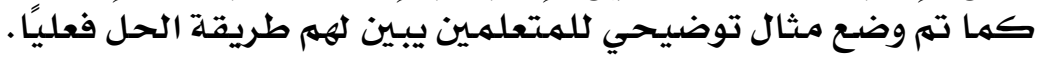
• صياغة هفردات الاختبار:

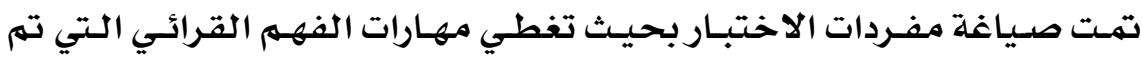
التوصل إليها، وهي جمـيعها أسئلة مـن نوع "اختيـار مـن متعددد". • إعداد الصورة الأولية للاختبار:

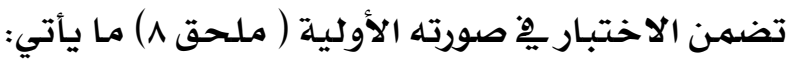
14 مقدمـة توضتح للمسحكمـين الهدف مـن إعداد الاختبـار.

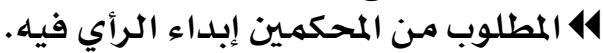

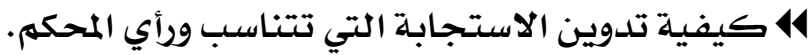
14 التعريف الإجرائي لمهارات الفهمه القرائي.

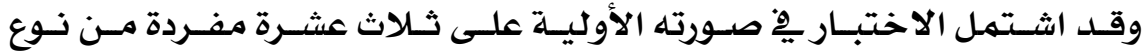
الاختيـار مـن متعـدد بهعـدل مفـردة واحـدة لكل مهارة إجرائيـة مـن مهارات الفهـهم القرائي. • عرض الاختبار في صورته الأولية على المكمين:

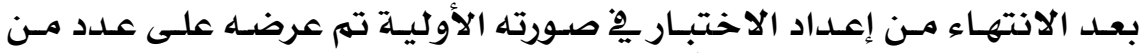

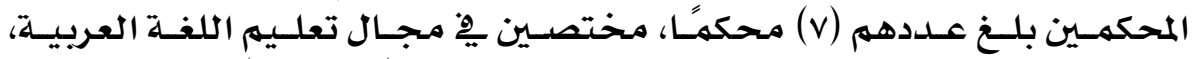

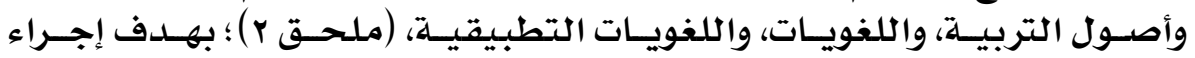

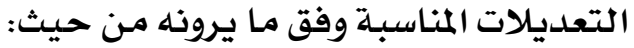

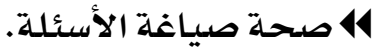
14 قياس السؤال كلهمهارة.

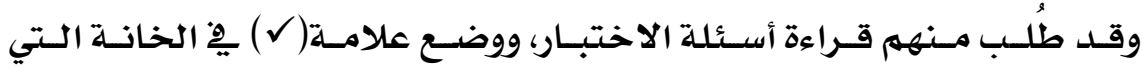
تتناسب ورأيهم. • إجراء التعديلات على الاختبار وفقًا لالموظات المكمين.

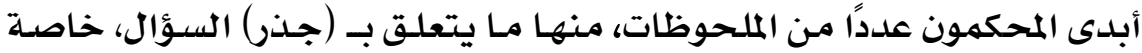

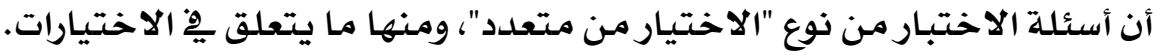
وقد تم إجـراء كـل التعـديلات السـابقة على الاختبـار؛ وذلكك لتطبيقـه على العينـة الاستطالاعيـة. • تطبيق الاختبار على عينة استطلاعية :

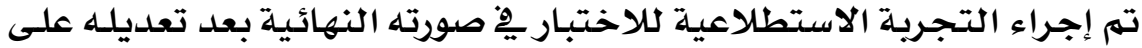

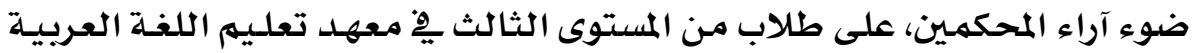




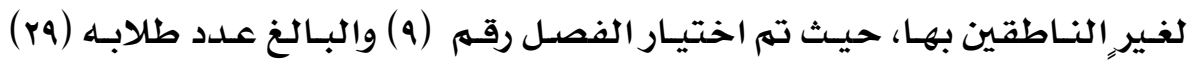

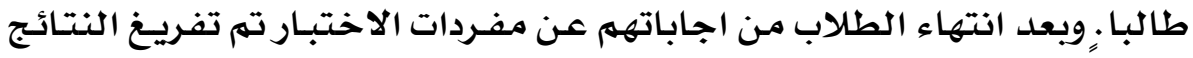

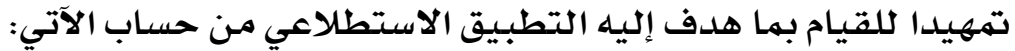
4 همامل ثبات الاختبار.

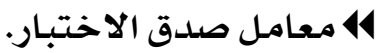

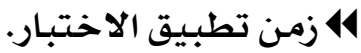

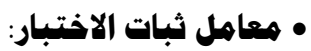

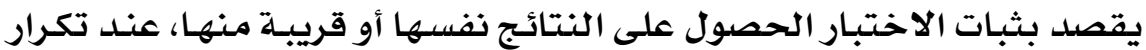

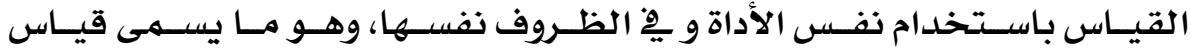

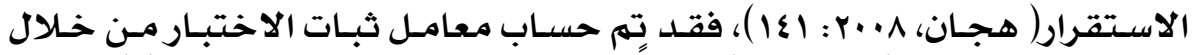

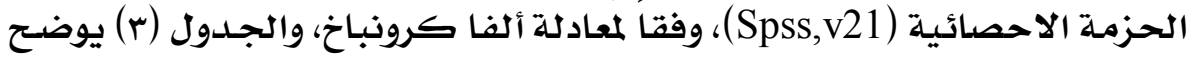
قيمـة معامل الثبات للاختمبـار. جلول (r) : معامل الفا كرونباخ لاختبار مهارات الفهمر القرائي

\begin{tabular}{|c|c|}
\hline مهارات تحليل النص الأدبي & معامل الثبات \\
\hline 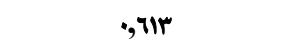 & ععامل ألفا كرونباخ \\
\hline
\end{tabular}

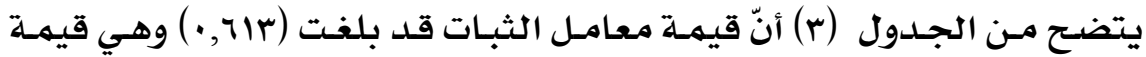
تدل على ارتفاع نسبة ثبات الاختبـار.

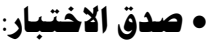

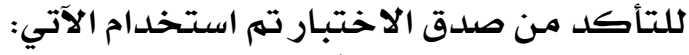

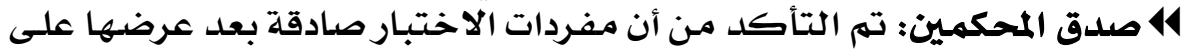

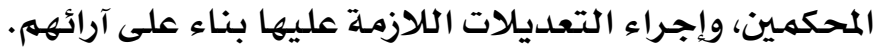

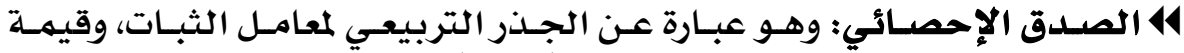

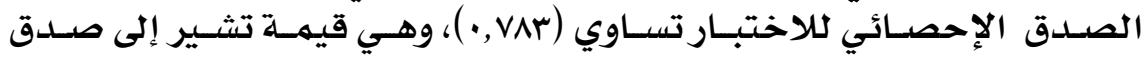
الاختبـار.

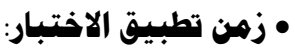

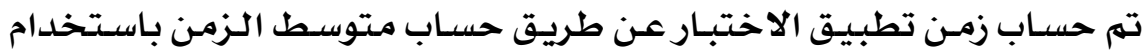
المعادلة الآتية: زمن الاختبار =زممن أول طالب انتهى من الاجابة (.rد) + آخر طالب انتهى من الاجابة ( مدد) وبتطبيـق المعادلـة كـان متوسط زمـن الاختبـار ( •عد)، وهـو زمـن مناسـب لأداء 


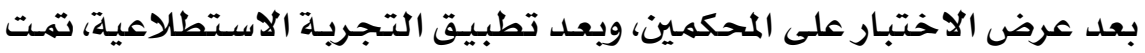

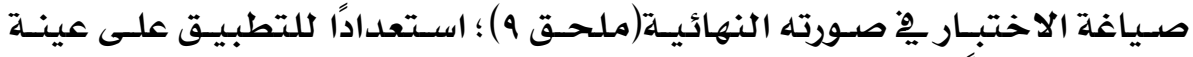
البحث،وقد تكوَّن الاختبار بِّ صورته النهائه النهية من ثلاث عشرة مفردة.

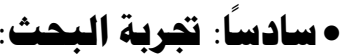

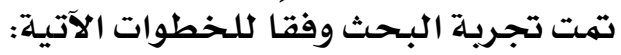

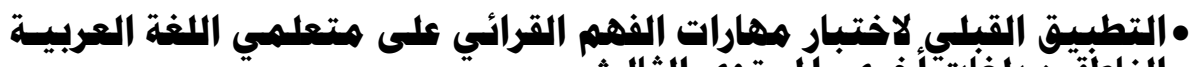

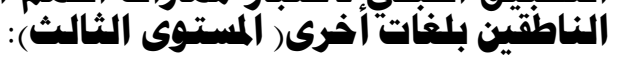

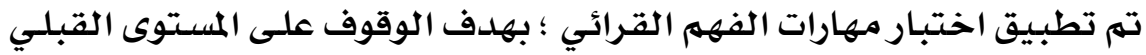

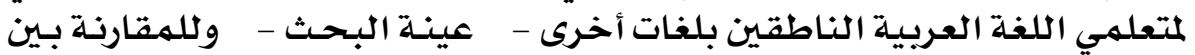

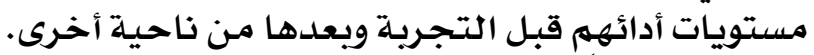

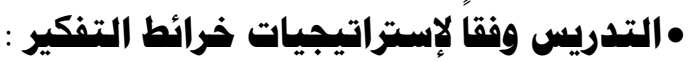

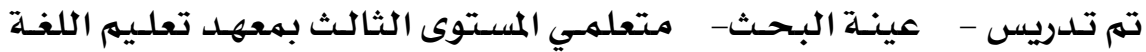

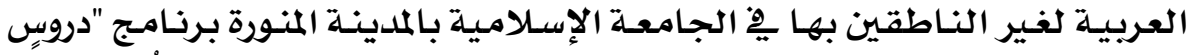

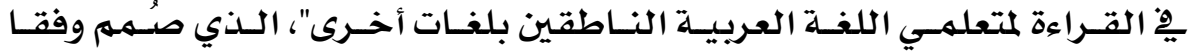

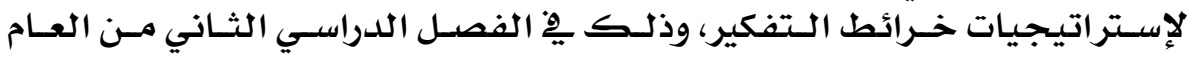

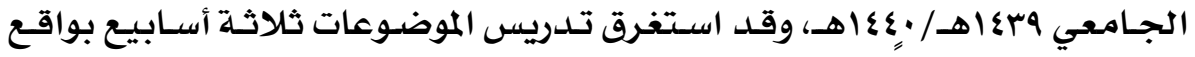
أريع ساعات أسبوعيا.

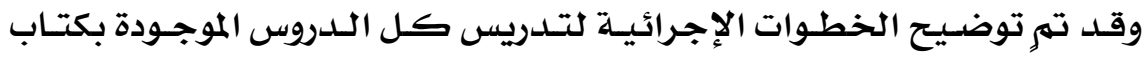

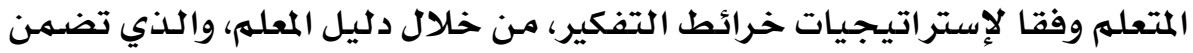

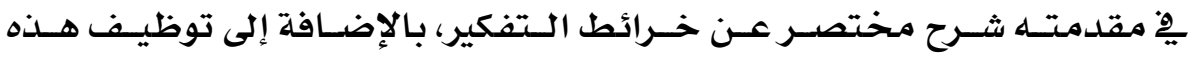
الإستراتيجيات ِِّن كل درس.

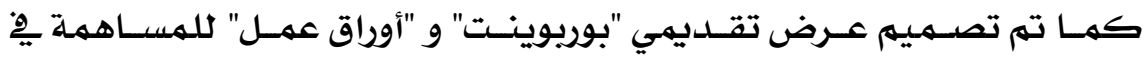

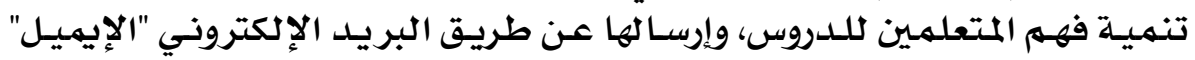

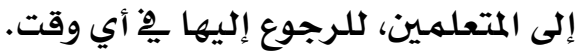

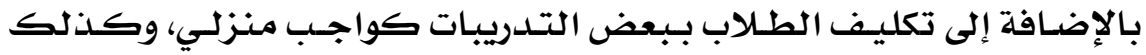

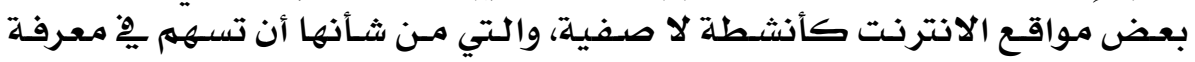
مدى فهم المتعلمين لمات تعلموه. •التطبيق البعدي لاختبار مهارات الفهم القرائي على متعلمي الفئهة العربية الناطقين بلغات آخرى لاخبار المستوى الثالث):

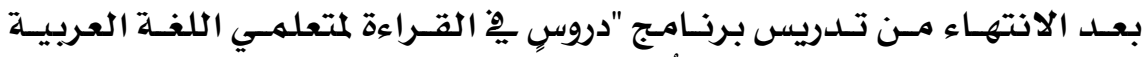

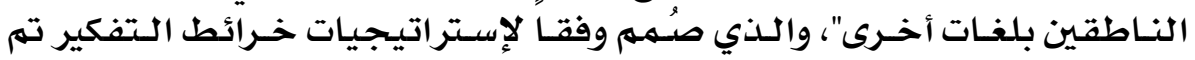

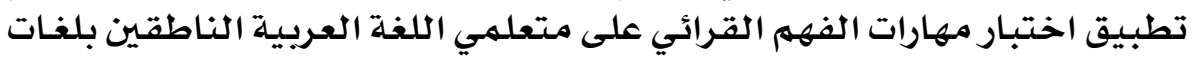




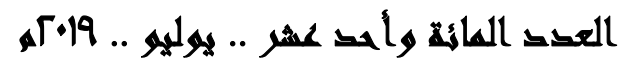

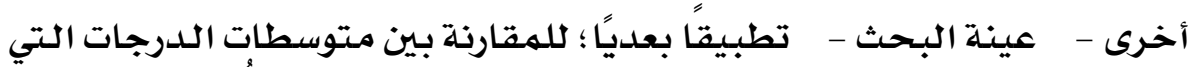

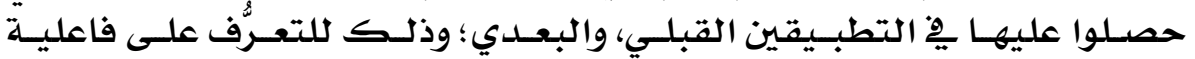

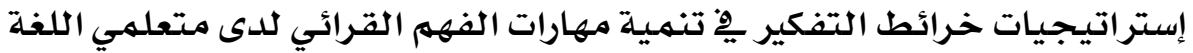

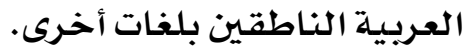

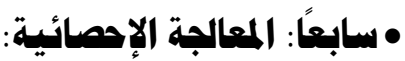

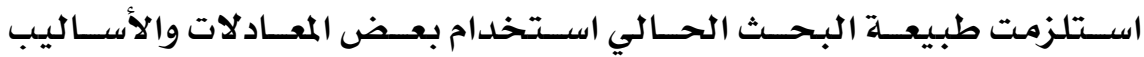

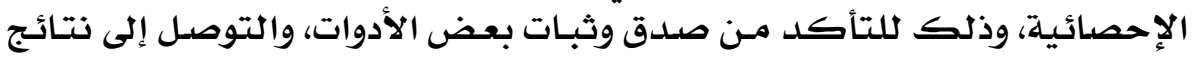

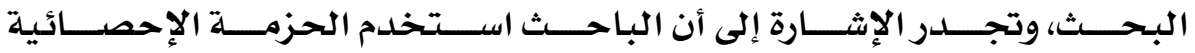

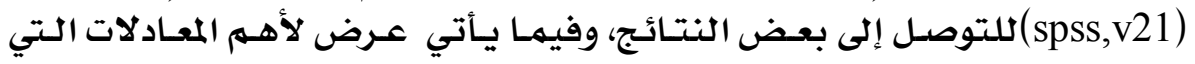

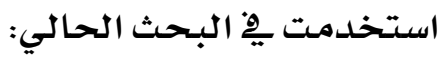

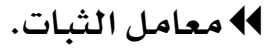

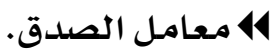
14 المتوسط الحسبابي. 14

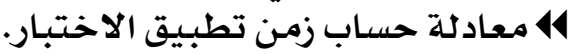
14 الانحراف المعياري.

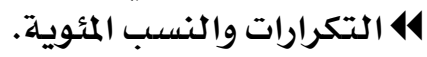
\اختبار "ت" للعينات المرتبطة (-Samples T-Test Paired).

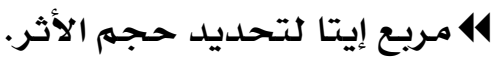

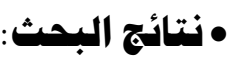

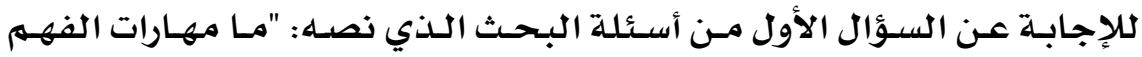

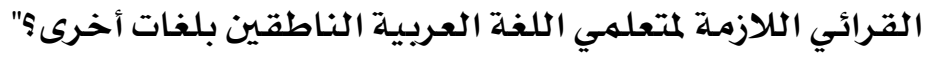
تم التوصل إلى قائمهة بههارات الفهم القرائي لمتعلهي اللغـة العربية النـاطقين

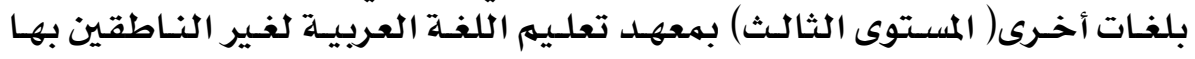

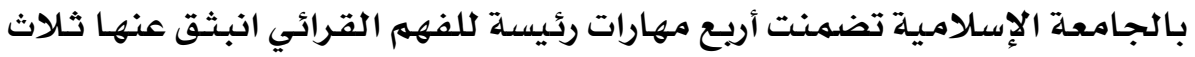
عشرة مهارة فرعيـة، كها يأتي: اولاً: همارات الفهم الحرفي: وانبثق عنها المهارات الآتية:

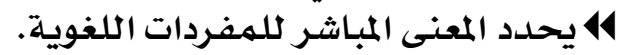

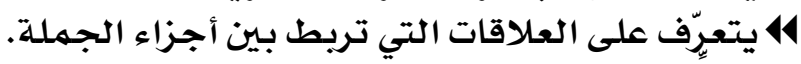

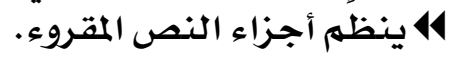

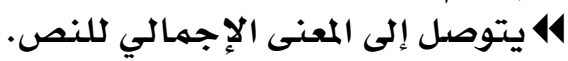

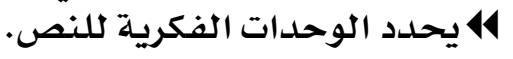
ثانياً: ههارات لفهم التفسيري: وانبثثق عنها المهارات الآتية:

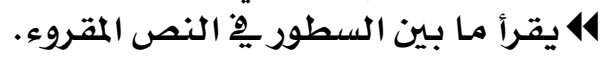




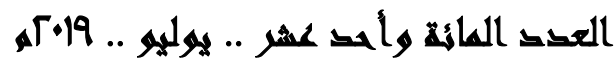

414 يستنبط المحاني الضمنية يِّ النص المقروء. 14 يختار عنوان مناسب للنص. 14 414 يستنتج علاقات السبب والنتيجة يِّ النص.

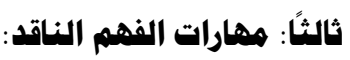

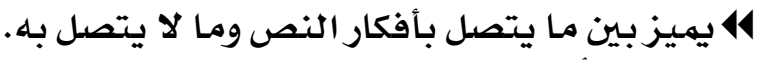
14 يتنباً بالأحداث بناء بـاء على مقدمار بات معينة.

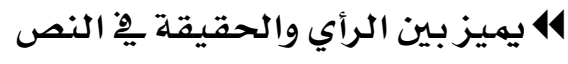

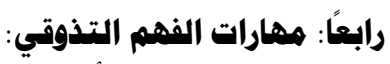
14 يحدد التعبير الأجمل من بين التعبيرات المقدمة يِّ النص.

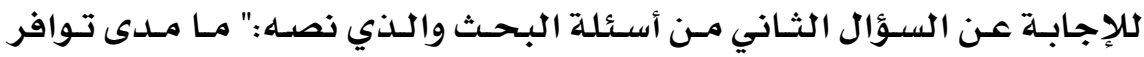

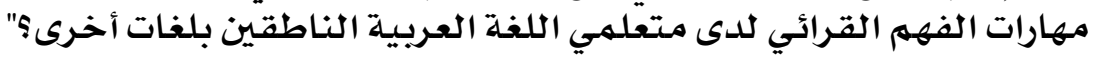

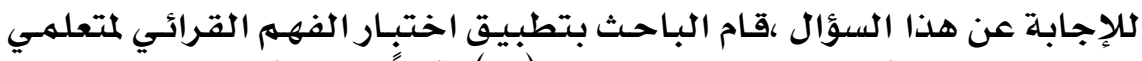

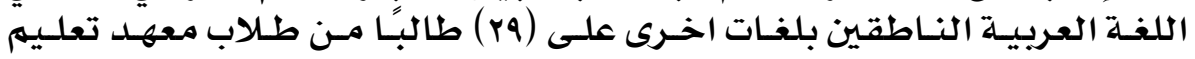

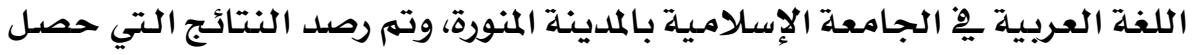

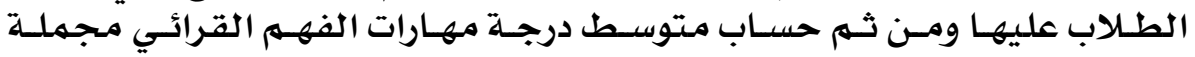
ودرجة كل محور على حدة.

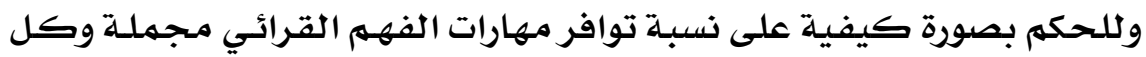

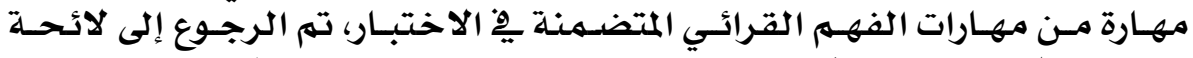

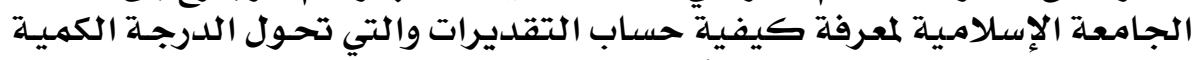

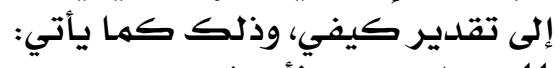

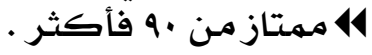
|4 414

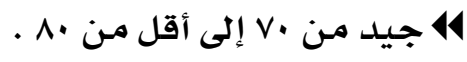

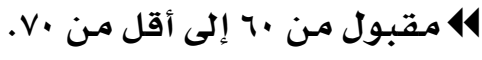
414

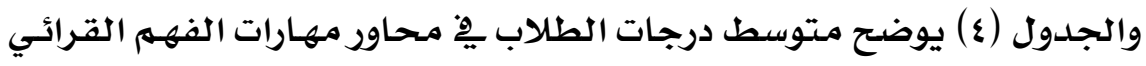

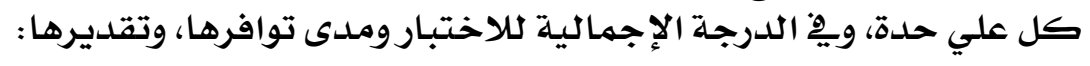

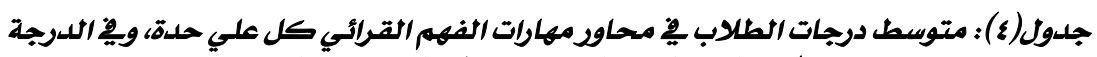
الإجمالية للاختباروملدي توافرها، وتقديرانها

\begin{tabular}{|c|c|c|c|}
\hline التقدير & نسبت التوافر & متوسط الدرجت & المحور \\
\hline ضعيف & $r \cdot r_{*}$ & 1,01 & الفهم الحري2 \\
\hline ضنعيف & 07,** & Y,YE & الفهم التفسيري \\
\hline ضغعيف & ع) & $1, r \varepsilon$ & الفهم الناقد \\
\hline خغعيف & 10,04 & 0 & الفهم التتنوقي \\
\hline ضغعيف & rq, r & $0,1$. & المحاور مسحملة \\
\hline
\end{tabular}


يتضـح مـن الجـدول(ع) أن نسـبـة تـوافر مهـارات الفهـهم القراتِي لـدى متعلهـي

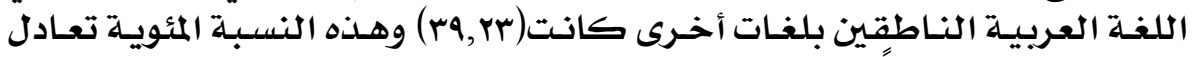

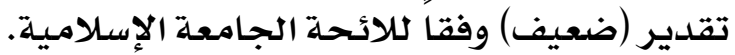

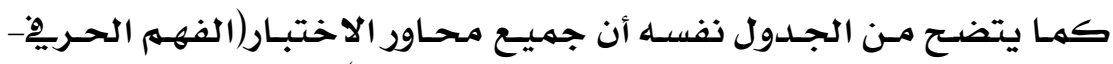

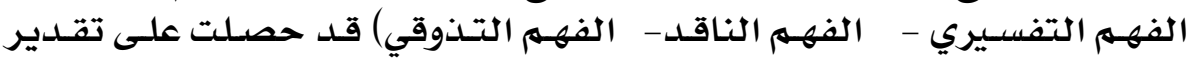
ضعحيف.

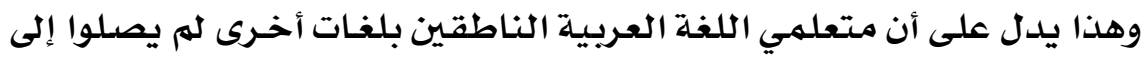

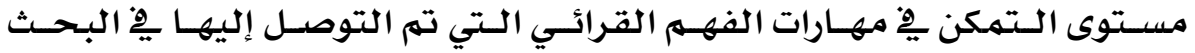

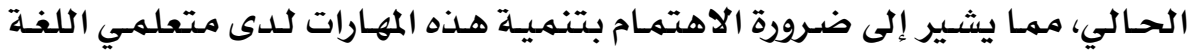

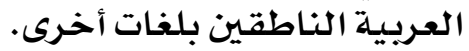

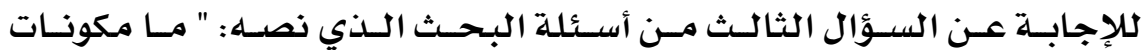

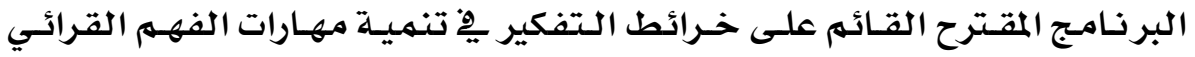

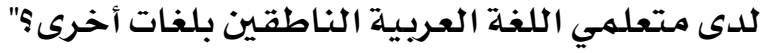

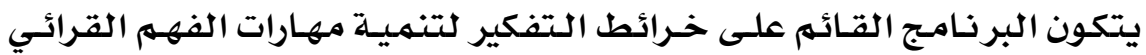

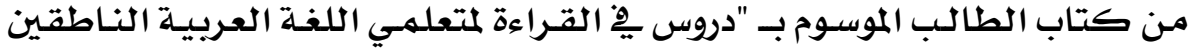

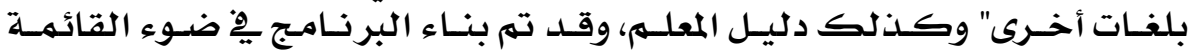

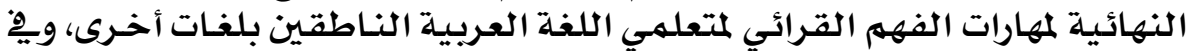

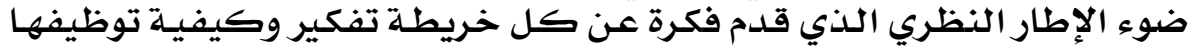

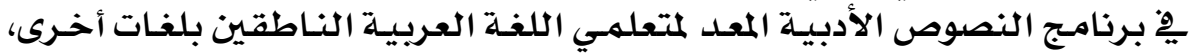
وكذ كك بعض أدلة المعلم التي تخدم نفس المجال، وهذه المكونات كها يأتي:

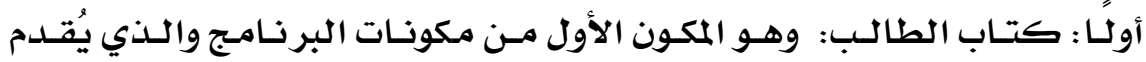
كلطادب، ويحتوي على ثلاثة دروس.

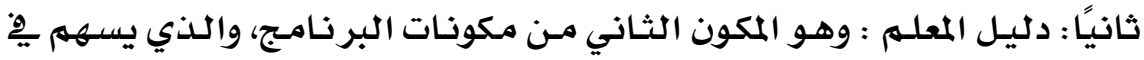

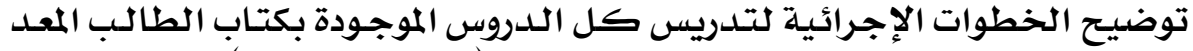

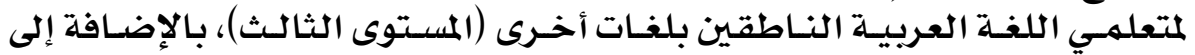

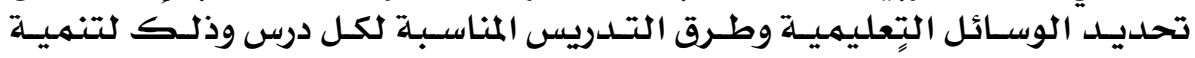

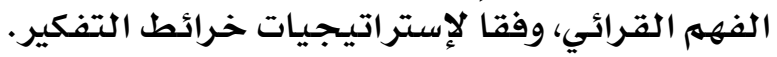

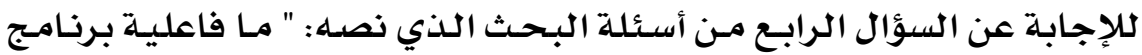

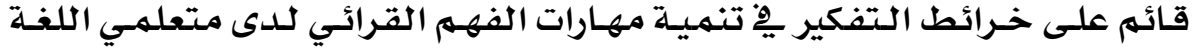

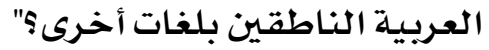
قام البـاحث بحسـاب مـتوسط الفرق بـين درجـات الطلاب يخ التطبـيقين القبلي

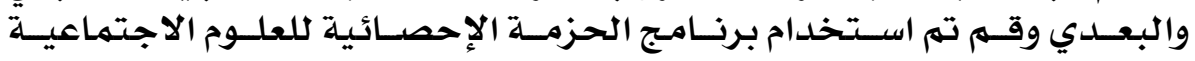


وذلــك بـاسـتخدام معادلــة اختبــار "ت" لعينـتين مـرتبطتين (SPSS, V.23) .( Paired-Samples T Test)

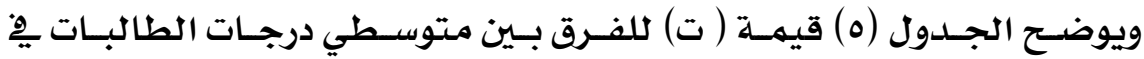

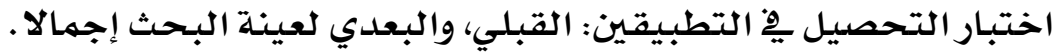

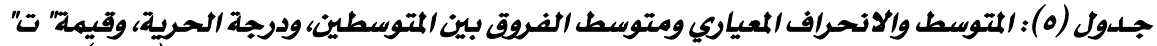

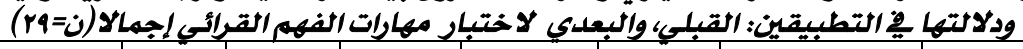

\begin{tabular}{|c|c|c|c|c|c|c|c|}
\hline الإحصائيتي & قتيمة & الحريتية & الفروقط & الانحمراف & المتوسط & التطبيق & المحيان \\
\hline \multirow{2}{*}{ دالت عند مستوى } & \multirow{2}{*}{$T, \wedge V$} & \multirow{2}{*}{ Yq } & \multirow{2}{*}{$\varepsilon, \&$} & r, 99 & $0,1$. & القبلي & \multirow{2}{*}{ الفهمبار مهارائي } \\
\hline & & & & $r, v r$ & $1 ., v r$ & البعدي & \\
\hline
\end{tabular}

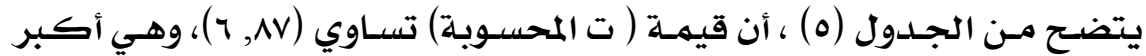

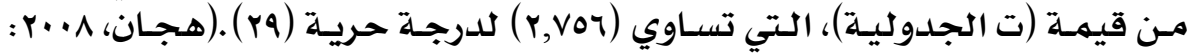

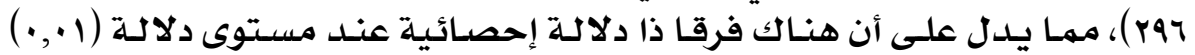

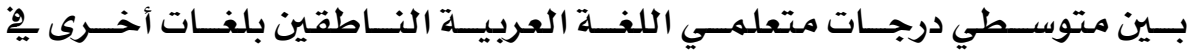

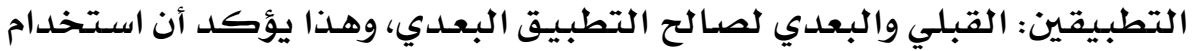

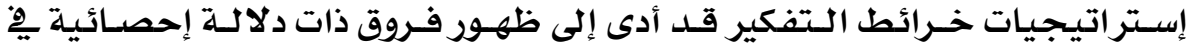

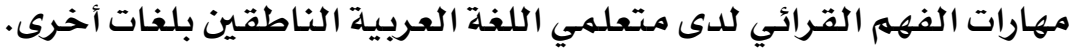

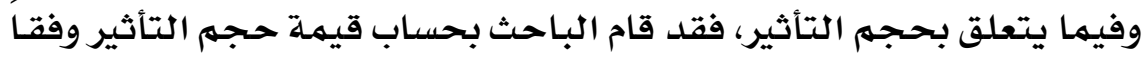

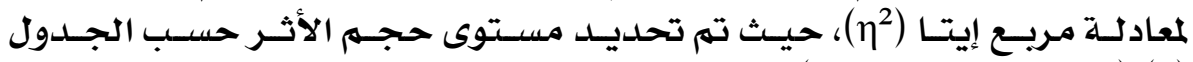

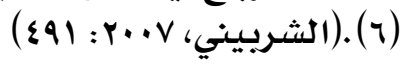
جلدول( ) ) جلدول تحلديد مستوى الأثر

\begin{tabular}{|c|c|c|c|}
\hline \multicolumn{3}{|c|}{ مستوى حجم الأثر } & \multirow{2}{*}{ المقياس } \\
\hline كبير & متوسط & منخفض & \\
\hline ז, •جمريع إيتا & ז, •> مريع إيتا > ז, . & r, •> مريع إيتا & 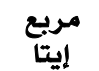 \\
\hline
\end{tabular}

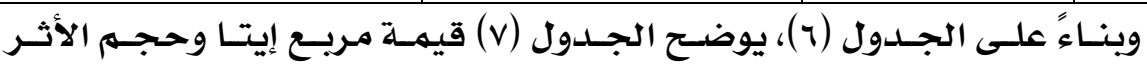

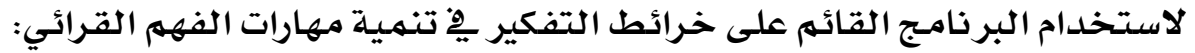

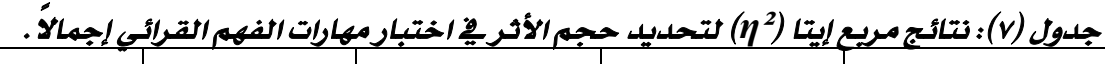

\begin{tabular}{|c|c|c|c|c|}
\hline حجم التأثير & 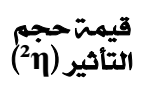 & درجات الحريت & قيمت"ت" & المحيان \\
\hline تأثير كبير & , v^ & rq & $T, A V$ & اختبار مهارات الفئهم \\
\hline
\end{tabular}

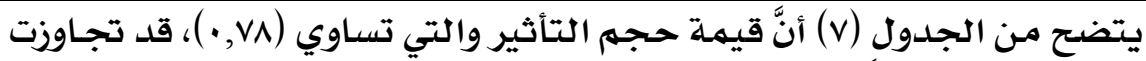

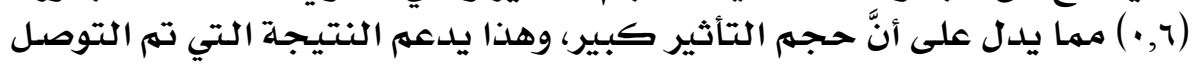




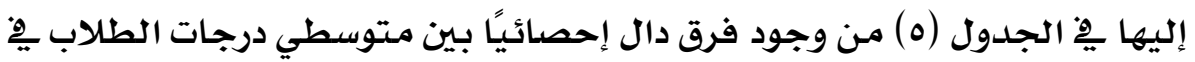

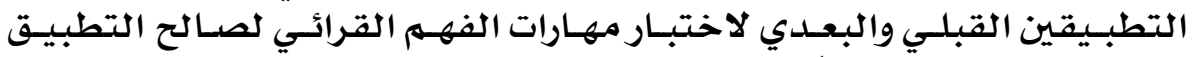

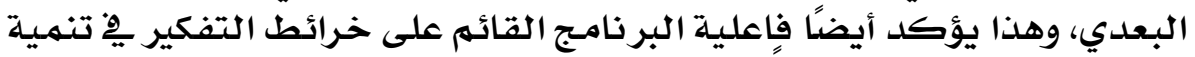

$$
\text { • مهارات الفهم القرائي إجماتيا. }
$$

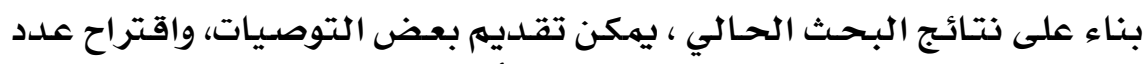

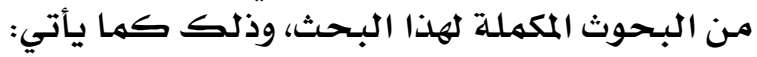

• التوصيات:

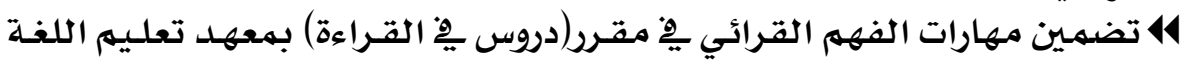

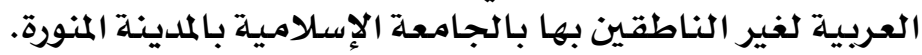

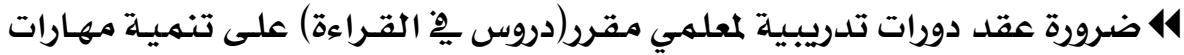

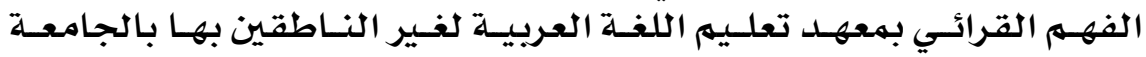

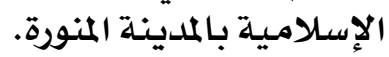

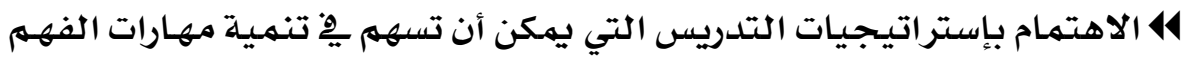

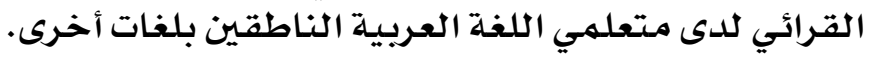

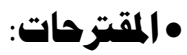

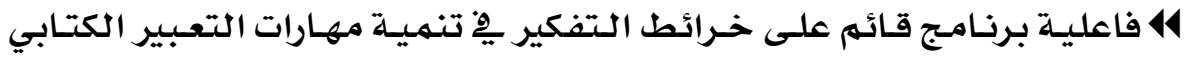

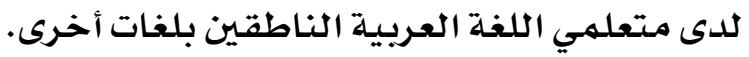

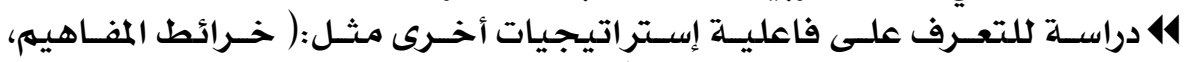

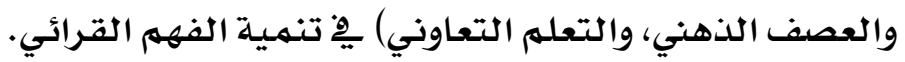

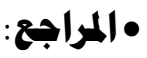

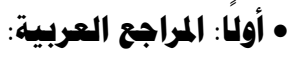

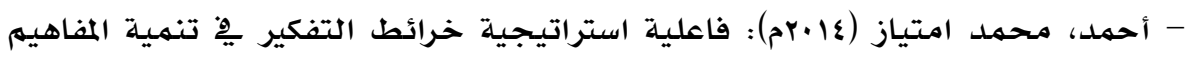

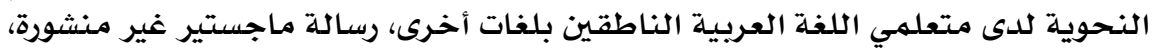

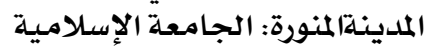

- جاب الله، علي سعد؛ وآخرون (11 المبرم):تعليم القراءة والكتابة أسسه وإجراءاته التربوية، الأردن:دار المسيرة.

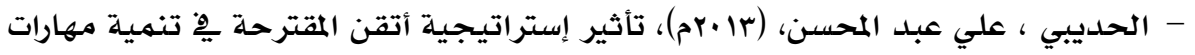

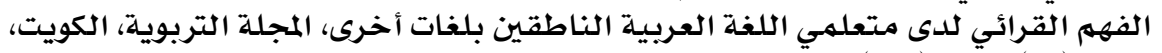

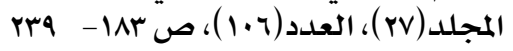

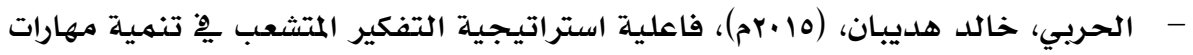

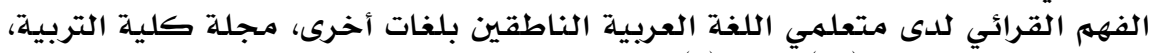

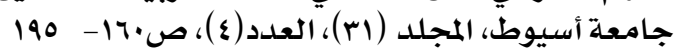




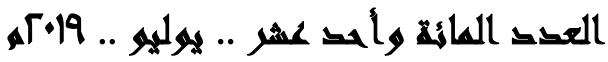

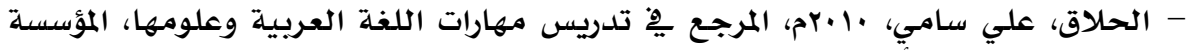
الحديثة للكتاب، الأردن،

- الخفاف، إيمان عباس (IV) إبم): خرائط التفكير طريقك إلى النجاح، الإمارات العربية

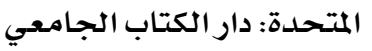

- الراجحي، عبده (990ام):علم اللغة التطبيقي وتعليهم العربية:دار المعرفة الجامعية، الاسكندريـة احسحية

- السلهي، ميمون أحمد ، (rامبrم)، صعوبات تعلهم القراءة لدى الطلاب غير الناطقين

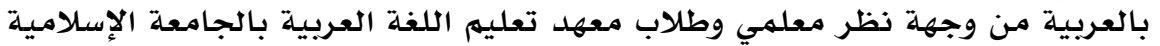

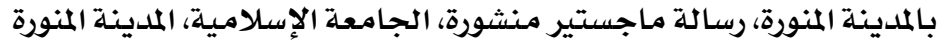

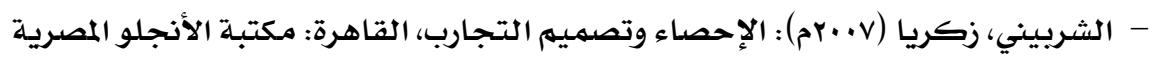
- ثعيب، أبو بكر عبدالله، (ع أبrم)، المهارات اللغويـة ( مفهومها - أهدافها - طرق تدريسها -

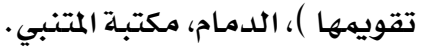

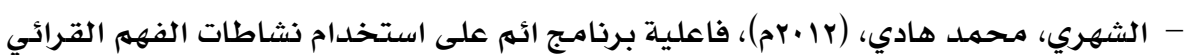

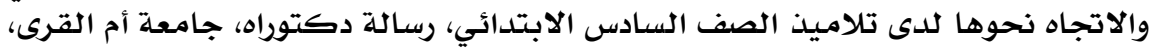

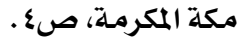

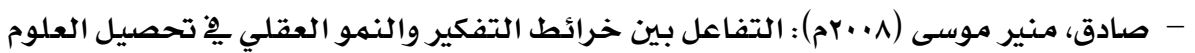

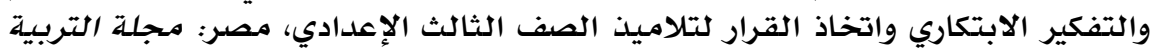

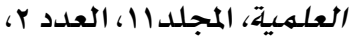

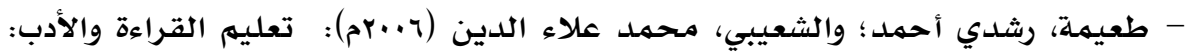

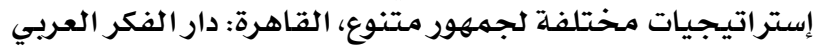

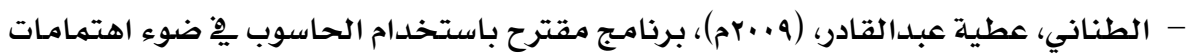

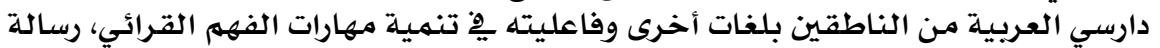

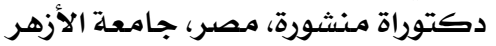
- عبدالباري، ماهر شعبان (·r.rم): سيكولوجية القراءة وتطبيقاتها التربوية، الأردن: دار المسيرة

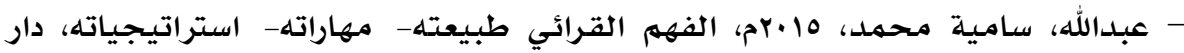

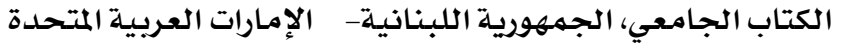

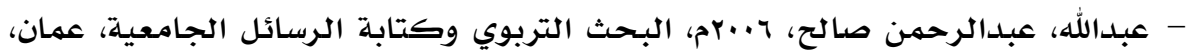

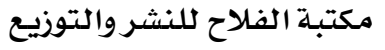
- عجاج، خيري المغازي (1991م) :صعوبات القراءة والفهم القرائي، مصر: دار الوفاء

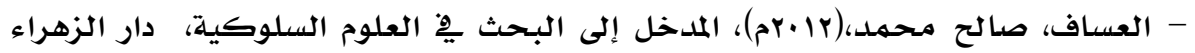

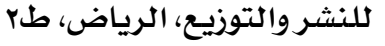




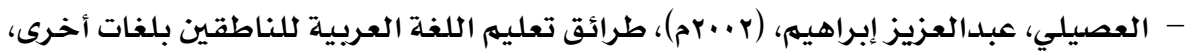

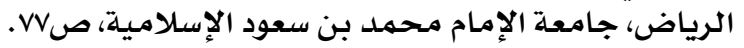

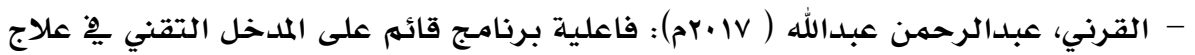

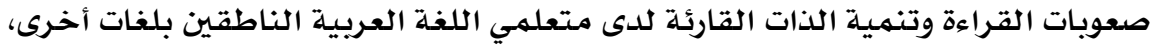

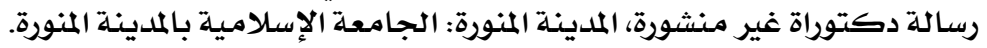

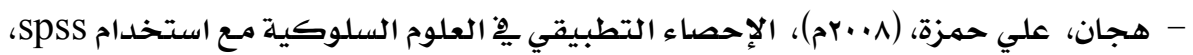

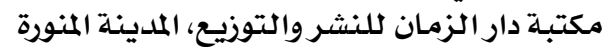

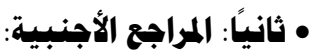

-Hyerle, David, (2009), Thinking Maps: Visual Tools for Activating Habits of Mind, Learning and Leading with Habits of Mind, (16 Essential Characteristics for Success), Association for Supervision and Curriculum Development - Alexandria, Virginia USA, p1

-Meissner, J., \& Yun, T. C.(2008) Verbal Solution Guide. Manhattan: Manhattan Review.

-Hyerle, David \&Alper, Larry:(2011) Student successes with Thinking Maps, CORWIN, California USA.

溇溇潾潾 